OPEN ACCESS

Edited by:

Xue-Rong Zhou,

Agriculture and Food, Commonwealth

Scientific and Industrial Research

Organisation (CSIRO), Australia

Reviewed by:

Rita Maggini,

University of Pisa, Italy

Mónika Alejandra

Valdenegro-Espinoza,

Pontificia Universidad Católica

de Valparaíso, Chile

*Correspondence:

Wee Sim Choo

choo.wee.sim@monash.edu

Specialty section:

This article was submitted to

Plant Metabolism

and Chemodiversity,

a section of the journal

Frontiers in Plant Science

Received: 10 October 2021

Accepted: 25 November 2021

Published: 17 December 2021

Citation:

Vidana Gamage GC, Lim YY and Choo WS (2021) Anthocyanins From Clitoria ternatea Flower: Biosynthesis, Extraction, Stability, Antioxidant

Activity, and Applications.

Front. Plant Sci. 12:792303.

doi: 10.3389/fpls.2021.792303

\section{Anthocyanins From Clitoria ternatea Flower: Biosynthesis, Extraction, Stability, Antioxidant Activity, and Applications}

\author{
Gayan Chandrajith Vidana Gamage, Yau Yan Lim and Wee Sim Choo* \\ School of Science, Monash University Malaysia, Subang Jaya, Malaysia
}

Clitoria ternatea plant is commonly grown as an ornamental plant and possesses great medicinal value. Its flower is edible and also known as blue pea or butterfly pea flower. The unique feature of anthocyanins present in blue pea flowers is the high abundance of polyacylated anthocyanins known as ternatins. Ternatins are polyacylated derivatives of delphinidin 3,3',5'-triglucoside. This review covers the biosynthesis, extraction, stability, antioxidant activity, and applications of anthocyanins from Clitoria ternatea flower. Hot water extraction of dried or fresh petals of blue pea flower could be employed successfully to extract anthocyanins from blue pea flower for food application. Blue pea flower anthocyanins showed good thermal and storage stability, but less photostability. Blue pea flower anthocyanins also showed an intense blue colour in acidic $\mathrm{pH}$ between $\mathrm{pH} 3.2$ to $\mathrm{pH}$ 5.2. Blue pea flower anthocyanin extracts demonstrate significant in vitro and cellular antioxidant activities. Blue pea flower anthocyanins could be used as a blue food colourant in acidic and neutral foods. The incorporation of blue pea flower anthocyanins in food increased the functional properties of food such as antioxidant and antimicrobial properties. Blue pea flower anthocyanins have also been used in intelligent packaging. A comparison of blue pea flower anthocyanins with two other natural blue colouring agents used in the food industry, spirulina or phycocyanin and genipin-derived pigments is also covered. Anthocyanins from blue pea flowers are promising natural blue food colouring agent.

Keywords: blue pea, blue colourant, delphinidin, functional food, genipin, phycocyanin, spirulina, ternatin

\section{HIGHLIGHTS}

- Blue pea flower contains high amount of blue colour anthocyanins.

- Blue pea flower contains polyacylated anthocyanins called ternatins.

- Blue pea anthocyanins demonstrate good thermal and storage stability.

- Anthocyanins from blue pea flower is a good alternative to spirulina and genipin. 


\section{INTRODUCTION}

Food colourants play an important role in food industry altering or conferring colours to food to increase the customer attractiveness and sensory acceptability (Lin et al., 2018). Food colourants are classified as artificial and natural, based on their origin. Artificial food colours are chemicals which originate from coal tar derivatives, and most of them contain an azo group (Dilrukshi et al., 2019). Considering artificial blue colours, Brilliant Blue FCF (E133, FD\&C Blue No. 1) and Indigo Carmine/Indigotine (E132, FD\&C blue No. 2) are approved as food colours in the European Union and the United States. Patent Blue V (E131) is authorised as a food additive in the European Union (Directive 94/36/EC; US Food and Drug Administration (FDA, 2015). Artificial blue colourants are used in various types of food. A study done in the Iranian market found that Brilliant blue colourant was commonly found in edible ices, jelly, fruit drink powder, chocolate/ice cream powder, soft drink, syrup, and candy (Asadnejad et al., 2018). Natural food colours consist of pigments such as anthocyanins, carotenoids, chlorophyll etc. that are extracted from mainly plants and micro-organisms (Sen et al., 2019). The demand for food products with natural colouring agents has increased since consumption of synthetic colourings are believed to cause allergies, food intolerance, hyperactivity, irritability and sleep disorders in children (Feketea and Tsabouri, 2017). Pigments giving red, orange and yellow hues are widely available but only a few sources are available giving blue colour. Anthocyanins are present in fruits giving rise to blue colour (Choo, 2019). Apart from anthocyanins, commonly used blue colourants in the food industry are spirulina/phycocyanin (a protein extracted from cyanobacteria Spirulina platensis, from eukaryote algae such as Rhodophytes and Cryptophytes and Galdieria sulphuraria, a unicellular rhodophyte) and the blue colour pigments produced by the reaction between primary amines and genipin (a colourless iridoid from monoterpenes class extracted from fruits of both Genipa americana and Gardenia jasminoides Ellis) (Landim Neves et al., 2021). Both spirulina and the blue pigment derived from genipin possess both advantages and disadvantages, that are unique to them. For example, phycocyanin is stable in the presence of citric acid, sugar, and soluble in warm or cold water but being a protein, it tends to get denatured in elevated temperature, low $\mathrm{pH}$ and is highly unstable under light (Gustiningtyas et al., 2020). Genipin-derived pigments show good thermal, photostability but become unstable in the presence of ascorbic acid. From an industrial perspective, the extraction procedures to obtain blue pigments from both spirulina and genipin are complicated. The extraction of spirulina involves the chemical breakdown of cell walls of respective organisms and the production of genipin-derived pigments involves a synthesis step from its precursor (Buchweitz, 2016). Therefore, new sources of natural blue colour are needed.

Anthocyanins are the largest group of water-soluble pigments belonging to flavonoids, a subclass of the polyphenol family, contributing to the attractive orange, red, purple, violet, and blue colours of fruits, vegetables, and flowers (Jing and Giusti, 2007). More than 700 anthocyanins have been identified in nature and they play a vital role in pollination and protecting plant cells from ultra-violet (UV) radiation (Salehi et al., 2020). Anthocyanins are glycosides of anthocyanidins. Pelargonidin, cyanidin, peonidin, delphinidin, petunidin and malvidin are the most common anthocyanidins in the plant kingdom (Choo, 2019). Colour of the anthocyanins depend on the $\mathrm{pH}$ of the solution because the structure of the anthocyanins alters depending on the $\mathrm{pH}$ of the surrounding medium (Khoo et al., 2017). Anthocyanins have been used in traditional medicine and for colouring food since ancient times. The therapeutic effects of anthocyanins are mainly attributed to their antioxidant activities (Khoo et al., 2017). The structure of anthocyanins allows anthocyanins to display direct antioxidant activity toward radicals in two mechanisms named: hydrogen atom transfer (HAT) and single electron transfer (SET). In both mechanisms, the anthocyanin becomes a free radical itself, but it is more stable and the oxidative damage from the initial free radical is prevented (Garcia and Blesso, 2021). Anthocyanins have demonstrated several other health benefits such as antibacterial, antiproliferative, hypoglycaemic etc. (Yoon et al., 2018; Li et al., 2019; Yue et al., 2019). Therefore, the application of anthocyanins as food colourants should be encouraged to deliver these health benefits to consumers. Generally, anthocyanins are well known for their unstable nature since the stability of anthocyanins is influenced by factors such as chemical structure, $\mathrm{pH}$, temperature, light, presence of oxygen, solvent, the presence of co-pigments, metal ions, and enzymes (Vidana Gamage et al., 2021a). Blue colour anthocyanins are generally found in blue colour flowers and fruits. Clitoria ternatea flower is one anthocyanin source containing stable blue colour polyacylated anthocyanins (Abidin et al., 2019; Thuy et al., 2021). The presence of polyacylated anthocyanins, metal ions, other phenolic compounds and the resulting co-pigmentation effect may assist to form more stable and intense blue colours (Yoshida et al., 2009).

Clitoria ternatea L. commonly known as butterfly pea or blue pea is a perennial leguminous herb belonging to family Fabaceae having several beneficial agricultural and medical applications, such as fodder, nitrogen-fixing crop, an eco-friendly insecticide (Oguis et al., 2019), food colouring (Pham et al., 2019), and in traditional medicine for disorders such as anasarca and ascites (Lakshan et al., 2019). It is commonly grown as an ornamental plant and is also used for revegetation (Kosai et al., 2015). Blue pea plants are distributed in several countries all over the world such as Thailand, Malaysia, Kenya, Australia, the United States, Sri Lanka, Brazil, Cuba, Sudan etc. (Havananda and Luengwilai, 2019). Blue pea flower is being eaten as vegetables in Southeast Asia (Leong et al., 2017) and blue pea flower extract has been used in desserts and beverages in Southeast Asian countries such as Malaysia and Thailand (Pasukamonset et al., 2017). Polyacylated derivatives of delphinidin 3,3',5'-triglucoside, named "ternatins" are the major anthocyanins present in blue pea flower (Terahara et al., 1990; Vidana Gamage et al., 2021b). All ternatins carry the basic structure of delphinidin-3, 3', 5' -triglucoside. A series of 15 ternatins A1-A3, B1-B4, C1-C5 and D1-D3 have been discovered so far (Nair et al., 2015; Jeyaraj et al., 2020). This review focus on the biosynthesis, extraction, stability, antioxidant activity and applications of anthocyanins from blue pea flower. Specifically, 
the potential of using blue pea flower anthocyanins as a natural blue food colouring agent is also covered.

\section{BLUE PEA FLOWER ANTHOCYANINS}

Clitoria ternatea L./blue pea flower (Figure 1) is a rich source of polyacylated anthocyanins and their higher stability compared with non-acylated anthocyanins provide the advantage to be used as a natural food colouring agent (Buchweitz et al., 2012; Marpaung et al., 2019). Like all anthocyanins, the colour of blue pea flower anthocyanin extract also changes with $\mathrm{pH}$. At $\mathrm{pH}$ lower than 3.2 the red colour exists, from $\mathrm{pH} 3.2$ to 5.2 the colour changes from violet to blue, from $\mathrm{pH} 5.2$ until pH 8.2 light blue colour exists and from $\mathrm{pH} 8.2$ to $\mathrm{pH} 10.2$ the colour changes from light blue to dark green colour (Escher et al., 2020a). This colour change could be explained by the structural alteration occurring in anthocyanin molecules along with the change in $\mathrm{H}^{+}$and $\mathrm{OH}^{-}$ concentration in the medium. The red colour is attributed to the presence of flavylium ion, blue colour to the presence of the neutral quinoidal base and the green colour to ionic chalcone (Liu et al., 2014). In non-acylated anthocyanins, flavylium ion transforms to colourless carbinol pseudo base when $\mathrm{pH}$ increases. But in blue pea flower anthocyanins, the presence of acyl groups prevents the hydrolysis of flavylium ion to less stable carbinol pseudo base form and instead form the blue colour quinoidal that possess less sensitivity to $\mathrm{pH}$ changes in mildly acidic or neutral medium (Bridle and Timberlake, 1997). Therefore, blue pea flower anthocyanins could be used as a blue colouring agent in acidic and neutral food systems. Figure 2 shows the structural alteration of delphinidin-3-glucoside with increasing $\mathrm{pH}$ and formation of blue colour in blue pea flower anthocyanins.

\section{BIOSYNTHESIS OF TERNATINS}

The anthocyanin biosynthetic pathway is an extension of the general flavonoid pathway (Tanaka et al., 2009). Anthocyanin biosynthesis pathway is an elucidated metabolic pathway involving enzymes such as chalcone synthase (CHS), chalcone isomerase $(\mathrm{CHI})$, flavanone 3-hydroxylase $(\mathrm{F} 3 \mathrm{H})$, flavonoid $3^{\prime}$-hydroxylase $\left(\mathrm{F} 3^{\prime} \mathrm{H}\right)$, flavonoid $3^{\prime}, 5^{\prime}$-hydroxylase $\left(\mathrm{F}^{\prime} 5^{\prime} \mathrm{H}\right)$, dihydroflavonol 4-reductase (DFR), anthocyanidin synthase (ANS), glycosyltransferase (GT), and acyltransferase (AT). Anthocyanins are synthesised in the cytoplasm of the cell and then transported to the vacuole. The vacuolar transportation of anthocyanins takes place in several pathways that include endoplasmic reticulum-derived vesicles and a tonoplast-bound glutathione S-transferase-like transporter (Collings, 2019). However, acylation of anthocyanins, catalysed by acyltransferases (ATs) and the final modification of anthocyanins occurs after being transported to the vacuole (Lu et al., 2021).

Figure 3 shows the proposed ternatin synthesis pathway drawn based on the studies done by Kogawa et al. (2007a) and Tanaka et al. (2009). In the biosynthesis of ternatins, first delphinidin-3-O- $\beta$-glucoside is formed and then it is modified by further glucosylation and acylation. For the synthesis of

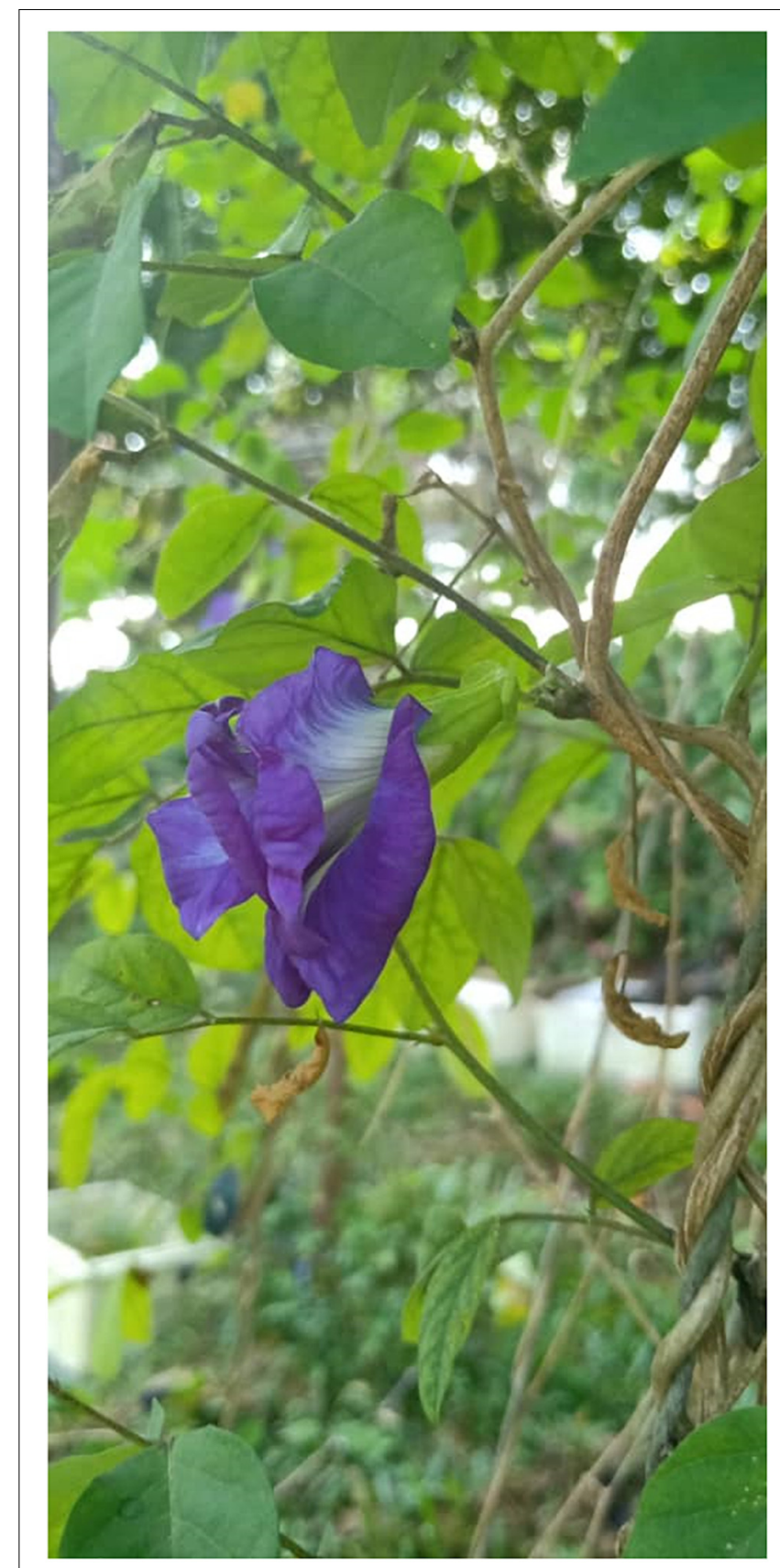

FIGURE 1 | Blue pea flower (Clitoria ternatea).

delphinidin-3-O- $\beta$-glucoside, 4-coumaroyl-CoA and malonylCoA act as precursors. Synthesis of the naringenin chalcone from the two precursors is mediated by CHS. CHS is the initial key enzyme of flavonoid biosynthesis. Then, naringenin chalcone is isomerised by $\mathrm{CHI}$ to naringenin. Naringenin is then converted to dihydrokaempferol in the presence $\mathrm{F} 3 \mathrm{H}$. Dihydrokaempferol is then converted to dihydromyricetin by $\mathrm{F}^{\prime} 5^{\prime} \mathrm{H}$. Both $\mathrm{F}^{\prime} \mathrm{H}$ and $\mathrm{F}^{\prime} 5^{\prime} \mathrm{H}$ are the enzymes responsible for the diversification of anthocyanins by determining their B-ring hydroxylation pattern and consequently the colour 


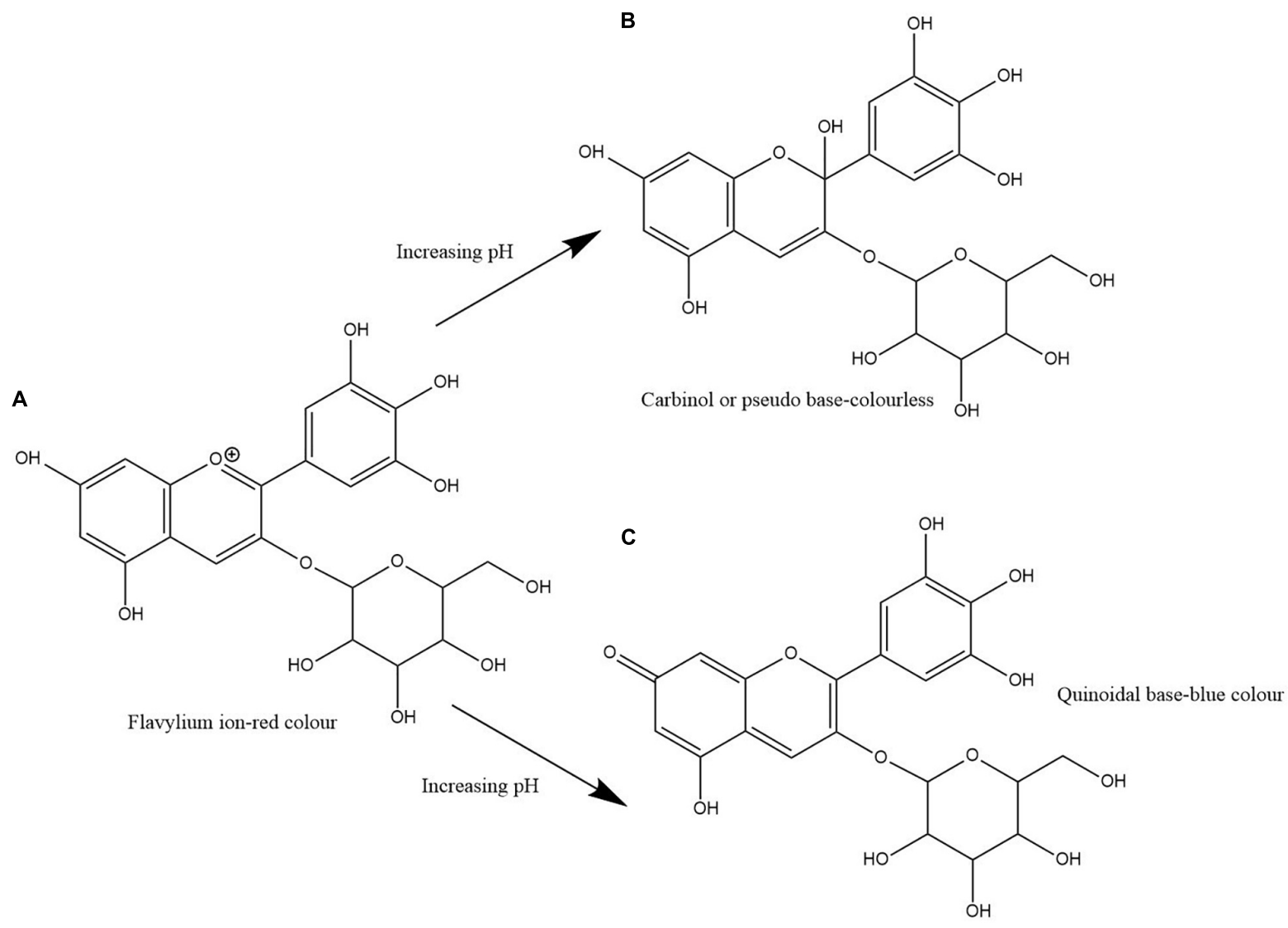

FIGURE 2 | Structural change of delphinidin-3-glucoside with increasing pH. Path (A,B) shows the transformation of flavylium ion to carbinol or pseudo base. Path $(\mathbf{A}, \mathbf{C})$ shows the transformation of flavylium ion to quinoidal base. Path $\mathbf{A}, \mathbf{C})$ shows the structural alteration responsible for the blue colour formation in blue pea flower anthocyanins.

of the anthocyanins (Liu et al., 2018). Therefore, F3' $5^{\prime} \mathrm{H}$ directly contribute to the blue colour anthocyanins in blue pea flower, since increased hydroxylation of the B-ring shifts the anthocyanin colour toward blue (Togami et al., 2006). Next, dihydromyricetin is converted into colourless leucodelphinidin mediated by DFR and subsequently to delphinidin by ANS. According to Kogawa et al. (2007a), a glucosyl group is added to delphinidin by anthocyanin 3-O-glucosyltransferase (3GT) to form delphinidin 3-O- $\beta$-glucoside. Kogawa et al. (2007a) stated that other glucosyl groups are added to the B-ring of delphinidin 3 -O- $\beta$-glucoside, only after malonylation of delphinidin 3$O-\beta$-glucoside. Accordingly, delphinidin $3-O-\beta$-glucoside is malonylated in the presence of anthocyanidin 3-O-glucoside 6" $O$-malonyltransferase (A6"MaT). Then, two glucose molecules are added to delphinidin 3-O-(6"-O-malonyl)- $\beta$-glucoside, first to $3^{\prime}$ position followed by $5^{\prime}$ position (Kazuma et al., 2004). This glycosylation is mediated by anthocyanin $3^{\prime}, 5^{\prime}-O-$ glucosyltransferase ( $\mathrm{UA3}^{\prime} 5^{\prime} \mathrm{GT}$ ) in two subsequent steps (Kogawa et al., 2007b). The molecule is now referred to as delphinidin 3 -O-(6" $6^{\prime \prime}-O$-malonyl) $-\beta$-glucoside- $3^{\prime}, 5^{\prime}$-di- $O-\beta$-glucoside and can be called as ternatin C5. Ternatin C5 is the simplest ternatin. Other 14 ternatins are synthesised by adding acyl and glucosyl groups to ternatin $\mathrm{C} 5$ in the presence of acyltransferases (ATs) and glucosyltransferases (GTs). Acyltransferases (AT) also plays a major role resulting in the blue colour and the stability of ternatins, because polyacylation of ternatins with p-coumaroyl groups results in a shift of colour of anthocyanins to bluish region due to intramolecular co-pigmentation among acyl moieties and between acyl moieties and anthocyanin chromophore (Honda and Saito, 2002). Furthermore, polyacylation at the $3^{\prime}$ position of anthocyanins results in stable blue colouration ( $\mathrm{Lu}$ et al., 2021). This is the main reason for the high stability of ternatins because most ternatins are polyacylated at the $3^{\prime}$ position. Therefore, when studying the ternatin biosynthesis pathway, hydroxylation, glycosylation and acylation can be considered as the most important steps that are responsible for synthesising stable blue colour anthocyanins in blue pea petals.

\section{EXTRACTION OF BLUE PEA FLOWER ANTHOCYANINS}

Extraction is the first important step in the recovery of active ingredients from plant materials (Jeyaraj et al., 2020). The purpose of selecting a suitable extraction method is 


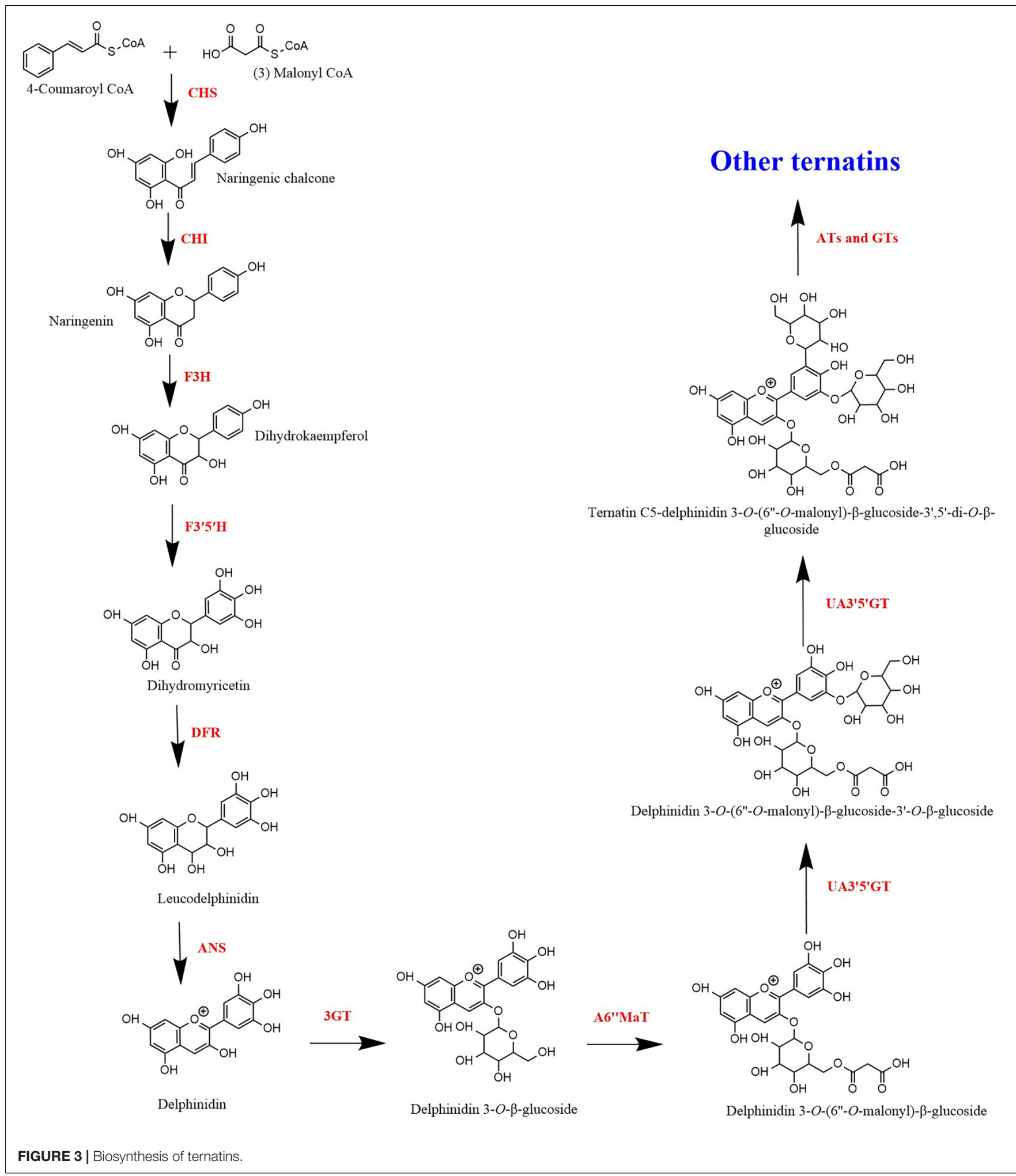

to obtain the maximum yield with a high concentration of target compounds. Since anthocyanins are sensitive to heat, light, acids and alkalis, selecting a suitable extraction method to get the maximum amount of anthocyanins without degradation is critical (Chandrasekhar et al., 2012; Jeyaraj et al., 2020).

Considering conventional solvent extraction methods, type of solvent, substrate: solvent ratio, extraction temperature, 
extraction time and soaking time may affect the extraction yield and total anthocyanin content (TAC) of a blue pea flower anthocyanin extract (Rocha et al., 2020). Selection of solvent should be done based on the application of the anthocyanin extract. Therefore, when anthocyanins from blue pea flowers are extracted for food application, the use of hazardous organic solvents should be avoided (Khoo et al., 2017; Chemat et al., 2019). Several studies have used hydro alcoholic extraction [i.e., 37\% ethanol (Jaafar et al., 2020), 50\% ethanol (Pham et al., 2019), $50 \%$ methanol (Shen et al., 2019)] to extract anthocyanins from blue pea flower. However, FDA (2018) has categorised methanol as a class 2 solvent having inherent toxicity and ethanol as a class 3 solvent that should be limited by good manufacturing practices (GMP) and other quality-based requirements. Distilled water is the best solvent for extracting anthocyanins for food applications because water could be considered as a non-toxic, non-flammable, and inexpensive green solvent (Chemat et al., 2019). Therefore, this review focuses only on the extraction of anthocyanins from blue pea flowers with water. Table 1 shows previous studies that carried out extraction of anthocyanins from blue pea flowers using water as the solvent.

Saptarini and Suryasaputra (2018) showed that the anthocyanin content of blue pea flower anthocyanin extract that was extracted using water at $\mathrm{pH} 1$ was higher than that of $\mathrm{pH}$ 2. This shows that the $\mathrm{pH}$ of water used for extraction can affect the TAC of the blue pea flower anthocyanin extract. Kang et al. (2021) suggested that the reason for obtaining a higher extraction efficiency when using more acidic solvents is the higher stability shown by the anthocyanins in acidic medium. Some studies use a soaking step before extracting anthocyanins. However, Shen et al. (2019) showed that soaking is not necessary when extracting anthocyanins from blue pea flowers using water. Soaking significantly reduced the TAC of the blue pea flower anthocyanin extract from 58.2 to $39.9 \mu \mathrm{g}$ cyanidin-3-glucoside/mL when the petals were soaked in water for $24 \mathrm{~h}$ but there was no significant difference in the TAC of the blue pea flower anthocyanin extract when soaking was carried out for 6 and $12 \mathrm{~h}$. The reason for the reduction of TAC due to soaking could be attributed to the increase of hydrolysis of anthocyanins when more water molecules are available in the matrix (Matsufuji et al., 2007; Marpaung et al., 2017). Therefore, extraction of anthocyanins from blue pea flower with water could be done without a soaking step that gives an advantage in time factor during the extraction process.

Considering substrate: solvent ratio, 1:20 $(\mathrm{g} / \mathrm{mL})$ was reported by Chusak et al. (2018) and Ahmad et al. (2020) as the best ratio for extraction of anthocyanins from blue pea flower (Table 1). The volume of water used for extraction is an important factor because less solvent would not extract a sufficient amount of anthocyanins from blue pea petals and excess water requires more energy for evaporation. Temperature around $50-60^{\circ} \mathrm{C}$ and extraction time around $20-60 \mathrm{~min}$ could be considered as the most suitable extraction temperature and time for extraction of anthocyanins from blue pea flower (Table 1) because higher temperature and long extraction time may result in deterioration of anthocyanins (Loypimai et al., 2016; Aprodu et al., 2020). High temperature and long extraction durations are disadvantageous in terms of energy consumption. Extraction conditions also affect the antioxidant activity of the blue pea flower anthocyanin extract. Shen et al. (2019) showed that the antioxidant activity of a blue pea flower anthocyanin extract was dependent on the solvent used for extraction and the soaking time upon extraction. However, there was no significant difference in the 2,2diphenyl1-picrylhydrazyl (DPPH) radical scavenging activity of blue pea flower anthocyanin extract that was extracted using distilled water without soaking (10.9 mM Trolox equivalents (TE)/g dry basis) and after soaking for $6 \mathrm{~h}$ (11.7 $\mathrm{mM}$ TE/g dry basis). Soaking in water up to $24 \mathrm{~h}$ significantly reduced the antioxidant activity of blue pea flower anthocyanin extracts ( $9.45 \mathrm{mM}$ TE/g dry basis) extracted by distilled water (Shen et al., 2019). Furthermore, the antioxidant activity of blue pea flower anthocyanin extract that was extracted with 50\% methanol (12.2 mM TE/g dry basis) was not significantly different in DPPH radical scavenging activity compared to blue pea flower anthocyanin extract that was extracted using distilled water (10.9 mM TE/g dry basis) at $0 \mathrm{~h}$ soaking. Similarly, Jeyaraj et al. (2021) also found that there was no significant difference in the antioxidant activity of the blue pea flower anthocyanin extracts obtained from water extraction and $50 \%$ ethanol extraction measured using DPPH and ferric reducing antioxidant power (FRAP) assays. This suggests that blue pea flower anthocyanins can be extracted using distilled water and used as a natural blue colouring agent with high antioxidant activity. Therefore, when extracting anthocyanins from blue pea flowers for food applications, hot water extraction with short extraction time is preferred.

Conventional solvent extraction techniques consume more solvents, time, thermal energy and are associated with several disadvantages. To overcome the shortcomings of conventional solvent extraction and to increase extraction efficiency, several non-conventional extraction techniques were explored. Ultrasonication is one such technique. In ultrasound-assisted extraction, acoustic cavitation causes molecular movement of solvent and sample results in the breakdown of plant cell walls and membranes and facilitate their movement to surrounding solvent (Chemat et al., 2011). One study employed ultrasound-assisted water extraction of blue pea flower anthocyanins and showed that ultrasound-assisted water extraction yielded $246.48 \%$ better anthocyanin extract yield compared with the conventional ethanolic extraction. According to that study, the TAC of the blue pea flower extract (1.126 mg delphinidin-3-O-glucoside equivalent/g) obtained by ultrasound-assisted water extraction was higher than that (0.325 mg delphinidin-3-O-glucoside equivalent/g) obtained by conventional ethanolic extraction (Gwee and Chong, 2015). Marsin et al. (2020) applied microwave-assisted extraction to extract blue pea flower anthocyanins, but the TAC of the blue pea flower anthocyanin extract obtained from microwave-assisted extraction did not show a higher value compared to the TAC of the blue pea flower anthocyanin extract obtained from conventional hot water extraction in the study by Ahmad et al. (2020) (Table 1). Therefore, the use of ultrasound-assisted extraction is promising to extract blue pea flower anthocyanins for food applications. When extracting anthocyanins from blue pea flower petals using water, other bioactive compounds 
that are soluble in water are also extracted together. Therefore, those compounds may also contribute to the antioxidant property of the anthocyanin extract and greater extraction efficiency could result in a higher antioxidant activity of the extract (Jeyaraj et al., 2020). The blue pea flower anthocyanin extract obtained by ultrasound-assisted extraction demonstrated

TABLE 1 | Previous studies on extraction of anthocyanins from blue pea flower using water and the antioxidant activity of extracts.

\begin{tabular}{|c|c|c|c|c|c|}
\hline Extraction technique & Optimum extraction condition & $\begin{array}{l}\text { Extraction } \\
\text { yield }\end{array}$ & Anthocyanin content & Antioxidant activity & References \\
\hline $\begin{array}{l}\text { Water extraction of } \\
\text { fresh petals }\end{array}$ & $\begin{array}{l}\text { Substrate: solvent ratio }-1: 20 \\
(\mathrm{~g} / \mathrm{mL}) \\
\text { Temperature }-60^{\circ} \mathrm{C} \\
\text { Time }-60 \mathrm{~min}\end{array}$ & $56.1 \%$ & $\begin{array}{l}4.0 \mathrm{mg} \\
\text { cyanidin-3-glucoside/g }\end{array}$ & $\begin{array}{l}\mathrm{IC}_{50}-1.18 \mathrm{mg} / \mathrm{mL} \text { in } \\
\text { DPPH radical } \\
\text { scavenging activity } \\
\text { FRAP assay-19.8 mg of } \\
\text { gallic acid } \\
\text { equivalent/g of extract } \\
\text { Inhibit reactive oxygen } \\
\text { species in RAW264.7 } \\
\text { cells by } 75-80 \%\end{array}$ & Jeyaraj et al., 2021 \\
\hline $\begin{array}{l}\text { Water extraction of } \\
\text { dried ground petals }\end{array}$ & $\begin{array}{l}\text { Substrate: solvent ratio }-1: 20 \\
(\mathrm{~g} / \mathrm{mL}) \\
\text { Temperature }-60^{\circ} \mathrm{C} \\
\text { Time }-60 \mathrm{~min}\end{array}$ & - & $\begin{array}{l}32.6 \mathrm{mg} \\
\text { cyanidin-3-glucoside/L }\end{array}$ & - & Ahmad et al., 2020 \\
\hline $\begin{array}{l}\text { Water extraction of } \\
\text { dried ground petals }\end{array}$ & $\begin{array}{l}\text { Temperature }-90^{\circ} \mathrm{C} \\
\text { Time }-5 \mathrm{~min}\end{array}$ & - & $\begin{array}{l}15.2 \mathrm{mg} \\
\text { delphinidin-3-glucoside } \\
\text { equivalent/g dried } \\
\text { flower }\end{array}$ & - & Voss et al., 2020 \\
\hline $\begin{array}{l}\text { Water extraction of } \\
\text { dried ground petals }\end{array}$ & $\begin{array}{l}\text { Substrate: solvent ratio }-1: 100 \\
(\mathrm{~g} / \mathrm{mL}) \\
\text { Temperature }-80^{\circ} \mathrm{C} \\
\text { Time }-30 \mathrm{~min}\end{array}$ & - & $\begin{array}{l}8.67 \mathrm{mg} \text { ternatin B2 } \\
\text { equivalent/g dried } \\
\text { flower }\end{array}$ & $\begin{array}{l}467.04 \mu \mathrm{mol} \text { Trolox } \\
\text { equivalent/g dried } \\
\text { flower in ABTS assay }\end{array}$ & $\begin{array}{l}\text { Vuong and } \\
\text { Hongsprabhas, } 2021\end{array}$ \\
\hline $\begin{array}{l}\text { Water extraction of } \\
\text { dried ground petals and } \\
\text { spray dried }\end{array}$ & $\begin{array}{l}\text { Substrate: solvent ratio }-1: 6(\mathrm{~g} / \mathrm{mL}) \\
\text { Temperature }-100^{\circ} \mathrm{C} \\
\text { Time }-120 \mathrm{~min}\end{array}$ & - & $\begin{array}{l}1.46 \mathrm{mg} \\
\text { cyanidin-3-glucoside/g }\end{array}$ & $\begin{array}{l}\mathrm{IC}_{50}-0.47 \mathrm{mg} / \mathrm{mL} \text { in } \\
\text { DPPH radical } \\
\text { scavenging activity } \\
\text { ORAC value- } 17.54 \mu \mathrm{g} \\
\text { trolox equivalents } / \mathrm{mg} \\
\text { dried extract } \\
\text { Protected erythrocytes } \\
\text { from APPH induced } \\
\text { haemolysis and } \\
\text { oxidation }\end{array}$ & $\begin{array}{l}\text { Phrueksanan et al., } \\
2014\end{array}$ \\
\hline $\begin{array}{l}\text { Water extraction of } \\
\text { dried ground petals and } \\
\text { partial purification of } \\
\text { lyophilised extract using } \\
\text { Amberlite XAD7HP } \\
\text { resin }\end{array}$ & $\begin{array}{l}\text { Substrate: solvent ratio }-0.125: 25 \\
(\mathrm{~g} / \mathrm{mL}) \\
\text { Temperature }-40^{\circ} \mathrm{C} \\
\text { Time }-30 \mathrm{~min}\end{array}$ & $2 \%$ & - & $\begin{array}{l}\text { The aqueous extract } \\
\text { showed } 43-64 \% \\
\text { inhibition for DPPH } \\
\text { radical scavenging } \\
\text { assay }\end{array}$ & Escher et al., 2020a \\
\hline
\end{tabular}


TABLE 1 | (Continued)

\begin{tabular}{|c|c|c|c|c|c|}
\hline Extraction technique & Optimum extraction condition & $\begin{array}{l}\text { Extraction } \\
\text { yield }\end{array}$ & Anthocyanin content & Antioxidant activity & References \\
\hline $\begin{array}{l}\text { Extraction of fresh } \\
\text { petals with water at } \mathrm{pH} \\
\text { 1and } 2\end{array}$ & $\begin{array}{l}\text { Substrate: solvent ratio }-1: 3(\mathrm{~g} / \mathrm{mL}) \\
\text { Temperature - room temperature } \\
\text { Maceration time }-24 \mathrm{~h} \\
\mathrm{pH}-1\end{array}$ & - & $\begin{array}{l}58.06 \text { mg } \\
\text { cyanidin-3-glucoside/L }\end{array}$ & - & $\begin{array}{l}\text { Saptarini and } \\
\text { Suryasaputra, } 2018\end{array}$ \\
\hline $\begin{array}{l}\text { Extraction of dried, } \\
\text { ground petals soaking } \\
\text { in distilled water }\end{array}$ & $\begin{array}{l}\text { Substrate: solvent ratio }-1: 20 \\
(\mathrm{~g} / \mathrm{mL}) \\
\text { Soaking time }-0 \mathrm{~h} \\
\text { Extraction temperature }-60^{\circ} \mathrm{C} \\
\text { Extraction time }-20 \mathrm{~min}\end{array}$ & - & $\begin{array}{l}58.2 \mu \mathrm{g} \text { cyanidin-3- } \\
\text { glucoside/mL }\end{array}$ & $\begin{array}{l}\text { IC } 50 \text { - } 10.9 \text { mM TE/g } \\
\text { in DPPH radical } \\
\text { scavenging activity } \\
\text { Inhibited seven-keto } \\
\text { cholesterol production } \\
\text { in an emulsion of } \\
\text { cholesterol and a free } \\
\text { radical generator by } \\
79.8 \%\end{array}$ & Shen et al., 2019 \\
\hline $\begin{array}{l}\text { Ultrasound-assisted } \\
\text { water extraction of } \\
\text { fresh petals }\end{array}$ & $\begin{array}{l}\text { Substrate: solvent ratio }-1: 15 \\
(\mathrm{~g} / \mathrm{mL}) \\
\text { Temperature }-50^{\circ} \mathrm{C} \\
\text { Time }-150 \text { min } \\
\text { Ultrasonic power }-240 \mathrm{~W}\end{array}$ & - & $\begin{array}{l}1.12 \text { mg delphinidin-3- } \\
\text { glucoside/g }\end{array}$ & - & $\begin{array}{l}\text { Gwee and Chong, } \\
2015\end{array}$ \\
\hline $\begin{array}{l}\text { Ultrasound-assisted } \\
\text { water extraction of } \\
\text { fresh petals }\end{array}$ & $\begin{array}{l}\text { Substrate: solvent ratio }-1: 50 \\
(\mathrm{~g} / \mathrm{mL}) \\
\text { Temperature }-60^{\circ} \mathrm{C} \\
\text { Time }-90 \text { min } \\
\text { Ultrasonic power }-100 \mathrm{~W}\end{array}$ & - & $1.42 \mathrm{~g} / \mathrm{L}$ & - & $\begin{array}{l}\text { Syafa'atullah et al., } \\
2020\end{array}$ \\
\hline $\begin{array}{l}\text { Ultrasound-assisted } \\
\text { water extraction of } \\
\text { fresh petals }\end{array}$ & $\begin{array}{l}\text { Substrate: solvent ratio }-1: 20 \\
(\mathrm{~g} / \mathrm{mL}) \\
\text { Temperature }- \text { room temperature } \\
\text { Time }-60 \text { min } \\
\text { Ultrasonic power }-560 \mathrm{~W}\end{array}$ & $36.1 \%$ & $\begin{array}{l}4.2 \mathrm{mg} \\
\text { cyanidin-3-glucoside/g }\end{array}$ & - & Jeyaraj et al., 2021 \\
\hline $\begin{array}{l}\text { Ultrasound-assisted } \\
\text { water extraction of } \\
\text { dried ground petals }\end{array}$ & $\begin{array}{l}\text { Substrate: solvent ratio }-1: 10 \\
(\mathrm{~g} / \mathrm{mL}) \\
\text { Temperature }-40^{\circ} \mathrm{C} \\
\text { Time }-45 \mathrm{~min} \\
\text { Ultrasonic power }-160 \mathrm{~W}\end{array}$ & - & $\begin{array}{l}1.77 \mathrm{mg} \\
\text { cyanidin-3-glucoside/g }\end{array}$ & $\begin{array}{l}\text { The aqueous extract } \\
\text { showed } 63.8 \% \\
\text { inhibition for DPPH } \\
\text { radical scavenging } \\
\text { assay }\end{array}$ & Salacheep et al., 2020 \\
\hline $\begin{array}{l}\text { Microwave-assisted } \\
\text { water extraction of } \\
\text { dried petals }\end{array}$ & $\begin{array}{l}\text { Substrate: solvent ratio }-1: 20 \\
(\mathrm{~g} / \mathrm{mL}) \\
\text { Microwave power }-770 \mathrm{~W} \\
\text { Time - } 1 \text { min }\end{array}$ & - & $\begin{array}{l}30.9 \mathrm{mg} \\
\text { cyanidin-3-glucoside/L }\end{array}$ & - & Marsin et al., 2020 \\
\hline
\end{tabular}

47.21\% more DPPH radical scavenging activity compared to the blue pea flower anthocyanin extract obtained from conventional ethanolic extraction (Gwee and Chong, 2015). Further studies need to be carried on investigating the effect of other novel extraction technologies such as high-pressure processing, sub-critical water extraction etc. to extract blue pea flower anthocyanins.

\section{STABILITY OF ANTHOCYANINS FROM BLUE PEA FLOWER}

The stability of anthocyanins is highly affected by $\mathrm{pH}$, temperature, light, metal ions in media etc. thus their application in food products is limited (Vidana Gamage et al., 2021a). Therefore, if anthocyanins are used as food colourants, those anthocyanins should possess reasonable thermal, photo and storage stabilities. This is because during food processing the food materials undergo several heat processes such as pasteurisation or sterilisation where else during storage, food must withstand storage conditions and photo stress (Charurungsipong et al., 2020). Several studies have investigated the stability of anthocyanins from blue pea flowers concerning their thermal, storage and photo stabilities.

Temperatures above $50^{\circ} \mathrm{C}$ cause partial or complete degradation of anthocyanins from natural sources and this results in a reduction of colour intensity (Escher et al., 2020a). Anthocyanins from blue pea flower demonstrate good heat stability in acidic $\mathrm{pH}$. Blue pea flower anthocyanins at $\mathrm{pH} 3.6$ and 5.4 showed stability at 60 and $70^{\circ} \mathrm{C}$. The absorbance remained unchanged for $360 \mathrm{~min}$ but when the temperature was increased from 70 to $100^{\circ} \mathrm{C}$, the degradation constant significantly increased. At $\mathrm{pH} 3.6$ the degradation rate constant increased from $5.57 \times 10^{-4}$ to $3.41 \times 10^{-3} \mathrm{~min}^{-1}$, when temperature increased from 80 to $100^{\circ} \mathrm{C}$ and at $\mathrm{pH} 5.4$ the degradation rate constant increased from $5.33 \times 10^{-4}$ to $3.32 \times 10^{-3} \mathrm{~min}^{-1}$ 
when temperature increased from 80 to $100^{\circ} \mathrm{C}$ (Escher et al., 2020a). Another study supports the above finding that the degradation rate of blue pea flower anthocyanins increases when the temperature is above $70^{\circ} \mathrm{C}$ (Lee et al., 2011).

One study investigated the degradation of anthocyanins from blue pea flowers at 28,60 , and $90^{\circ} \mathrm{C}$. The degradation half-lives at each temperature were $8.63,5.16$, and $3.75 \mathrm{~min}$, respectively. This shows how the degradation rate increased (half-life reduced) with increasing temperature. This study also showed that the addition of catechin as a co-pigment to the anthocyanin extract of blue pea flower at $\mathrm{pH} 3.5$ increased the half-life of anthocyanins from blue pea flower to 8.39 at $90^{\circ} \mathrm{C}$ (Charurungsipong et al., 2020). Catechin molecules also have a similar structure as anthocyanins where each molecule possesses two benzene rings and one dihydropyran heterocycle. A co-pigment complex is formed between catechin and ternatins by intermolecular copigmentation either as an interlock complex or parallel complex (Charurungsipong et al., 2020). The presence of several aromatic acyl groups in ternatins may increase the chance of forming several co-pigment complexes with the available co-pigments. Generally, most food products fall into the $\mathrm{pH}$ range of $\mathrm{pH}$ 3.6 to 5.4 and the pasteurising temperature also ranges between 60 and $70^{\circ} \mathrm{C}$ (Low-Temperature Long Time (LTLT) $-62.5^{\circ} \mathrm{C}$ for $30 \mathrm{~min}$ and High-Temperature Short Time (HTST) $-72^{\circ} \mathrm{C}$ for 15 seconds) (Ranieri et al., 2009). This stability makes anthocyanins from blue pea flowers suitable as a natural food colour in functional food. Another study investigated the storage stability of anthocyanins from blue pea flowers with different temperatures in terms of colour stability index (absorbance on sampling day/absorbance of day 0 ). This study showed that at frozen and refrigerated conditions the colour stability index of anthocyanins from blue pea flower reduced only by 0.2 points after 30 days of storage. At temperatures above $25^{\circ} \mathrm{C}$, the stability of blue pea flower anthocyanins reduced significantly. Their colour stability index reduced by 0.8 points during 20 days of storage at $25^{\circ} \mathrm{C}$. The storage stability of anthocyanins from blue pea flowers was significantly low when stored at temperatures above $50^{\circ} \mathrm{C}$ and the colour stability index reduced by 0.9 points in 15 days of storage at $50^{\circ} \mathrm{C}$ (Ab Rashid et al., 2021). Another study showed that, when anthocyanin extract from blue pea flower was stored at $5^{\circ} \mathrm{C}, 80 \%$ of initial anthocyanins were retained after 30 days and the residual colour remained almost unchanged for about one year and the stability reduced within a week when stored between 25 and $37^{\circ} \mathrm{C}$ but at $45^{\circ} \mathrm{C}$ again the anthocyanins from blue pea flower demonstrated good stability for more than 10 days (Lee et al., 2011). This could be due to the activation of enzymes that cause anthocyanin degradation since $37^{\circ} \mathrm{C}$ is the optimum temperature for enzyme activity (Daniel and Danson, 2013). Therefore, it is recommended to use anthocyanins from blue pea flowers for food stored in cold conditions (e.g., frozen desserts, yoghurt, cool drinks) and to store food containing anthocyanins from blue pea flowers in the freezer, refrigerator or temperatures below $25^{\circ} \mathrm{C}$.

Anthocyanins from blue pea flowers are less stable to photo stress compared to thermal stress (Mahmad and Taha, 2018). When anthocyanins from blue pea flowers were exposed to the direct light of a white fluorescent lamp $(20 \mathrm{~W})$ at $32^{\circ} \mathrm{C}$, the anthocyanins from blue pea flowers degraded at a higher rate compared with anthocyanins kept covered from light. Blue pea flower anthocyanins at $\mathrm{pH} 3.6$ had a $34.4 \%$ retention percentage when exposed to light whereas the covered anthocyanins had a $90.1 \%$ retention percentage after equal periods. Blue pea flower anthocyanins at $\mathrm{pH} 5.4$ had a $48.3 \%$ retention percentage when exposed to light whereas the covered anthocyanins had a $94.6 \%$ retention percentage after equal periods (Escher et al., 2020a). Anthocyanins from blue pea flower demonstrated higher photostability at $\mathrm{pH} 5.4$ compared with 3.6 but in both cases, the degradation rate looks high. But microencapsulation of anthocyanins from blue pea flowers was able to increase the photostability of blue pea flower anthocyanins (Marsin et al., 2020; Ab Rashid et al., 2021). Marsin et al. (2020) optimised the microwave-assisted encapsulation of blue pea flower anthocyanins and obtained an encapsulation efficiency of $73.24 \%$ with $40 \%(\mathrm{w} / \mathrm{w})$ maltodextrin at $770 \mathrm{~W}$ microwave power for $7 \mathrm{~min}$. Ab Rashid et al. (2021) reported an encapsulation efficiency of $87.3 \%$ using spray drying as the encapsulation technique and $20 \%(\mathrm{w} / \mathrm{w})$ maltodextrin as the carrier agent. When microencapsulated anthocyanins from blue pea flower with maltodextrin and control blue pea flower anthocyanins were exposed to light at $25^{\circ} \mathrm{C}$ and $\mathrm{pH} 5.5$, microencapsulated anthocyanins from blue pea flower showed a significantly higher colour stability index (colour stability index - 0.83) compared to the control anthocyanin extract from blue pea flower (colour stability index - 0.57) after 21 days (Ab Rashid et al., 2021). Therefore, when manufacturing food with blue pea flower anthocyanins as a food colourant, it is recommended to avoid using transparent packaging material to protect anthocyanins from direct light exposure or use an encapsulation technique.

The good thermal stability up to $70^{\circ} \mathrm{C}$, the storage stability at $25^{\circ} \mathrm{C}$ and the intense blue colour demonstrated at $\mathrm{pH} 3.6$ to 5.4 , makes anthocyanins from blue pea flowers, suitable to be used as a blue colour food colourant. Table 2 shows a comparison of extraction yield, thermal stability, photostability, antioxidant activity and aggregate formation in acidic beverages of natural blue colouring agents used in the food industry: phycocyanin, genipin-derived pigments and anthocyanins from blue pea flowers. The extraction yield on dry basis of blue pea flower anthocyanin extract was higher than that of phycocyanin and genipin (Table 2). One possible reason for obtaining a lower extraction yield could be the presence of structures such as hard cell walls and fibre in the sources of phycocyanin and genipin that hinders the extraction (Buchweitz, 2016). Considering $\mathrm{pH}$ stability, blue pea flower anthocyanins demonstrated higher stability in acidic $\mathrm{pH}$ compared to phycocyanin and genipinderived pigments.

Comparing the thermal stability of phycocyanin, genipinderived pigments and anthocyanins of blue pea flower (Table 2), phycocyanin was less stable at low-temperature long time pasteurisation conditions (at $63^{\circ} \mathrm{C}$ for $30 \mathrm{~min}$ ) but Chaiklahan et al. (2012) reported that the colour loss of phycocyanin in high-temperature short-time pasteurisation $\left(71^{\circ} \mathrm{C}\right.$ for $\left.15 \mathrm{~s}\right)$ was negligible. The thermal stability of genipin-derived pigments was higher in the alkaline medium compared with acidic and neutral media, but most of the blue coloured food products consist of an 
TABLE 2 | Comparison of common blue food colourants with anthocyanins from blue pea flower.

\begin{tabular}{|c|c|c|c|}
\hline & Phycocyanin & Genipin derived pigments & $\begin{array}{l}\text { Anthocyanins from blue pea } \\
\text { flower }\end{array}$ \\
\hline $\begin{array}{l}\text { Extraction yield (\% on } \\
\text { dry basis) }\end{array}$ & $\begin{array}{l}\text { 8.27-8.66\% (Chaiklahan et al., } \\
\text { 2018) }\end{array}$ & 10.7-11.8\% (Buchweitz, 2016) & 21-29\% (Mehmood et al., 2019) \\
\hline Thermal stability & $\begin{array}{l}\text { Unstable (40-75\% colour loss) at } \\
\mathrm{pH} 4 \text { and } 8 \text { when heated at } 65^{\circ} \mathrm{C} \\
\text { for } 30 \text { min. Stable below } 45^{\circ} \mathrm{C} \\
\text { (Patel et al., 2004) }\end{array}$ & $\begin{array}{l}\text { Stable at } \mathrm{pH} 9 \text { (colour remaining } \\
>90 \% \text { ) compared with } \mathrm{pH} 5 \text { and } 7 \\
\text { between } 60 \text { and } 90^{\circ} \mathrm{C} \text { for } 10 \mathrm{~h} \\
\text { (Paik et al., 2001) }\end{array}$ & $\begin{array}{l}\text { Stable at } 60 \text { and } 70^{\circ} \mathrm{C} \text { between } \mathrm{pH} \\
3.6 \text { and } 5.4 \text { for } 360 \text { min (Escher } \\
\text { et al., 2020a) }\end{array}$ \\
\hline Photostability & $\begin{array}{l}\text { Stable at } \mathrm{pH} 5 \text { for } 5 \text { days under } \\
\text { natural light and ambient } \\
\text { temperature, unstable at } \mathrm{pH} 3 \text { and } \\
7 \text { (Zhang et al., 2021) }\end{array}$ & $\begin{array}{l}\text { Stable (colour remaining }>90 \% \text { ) at } \\
\mathrm{pH} 7 \text { compared with } \mathrm{pH} 5 \text { and } 9 \text { for } \\
10 \text { h under } 5,000 \text { lux and at } 4^{\circ} \mathrm{C} \text {. } \\
\text { Stability reduced when light } \\
\text { intensity increased from } 5,000 \text { to } \\
20,000 \text { lux (Paik et al., 2001) }\end{array}$ & $\begin{array}{l}\text { Unstable to light (Escher et al., } \\
\text { 2020a) }\end{array}$ \\
\hline Antioxidant activity & $\begin{array}{l}\text { DPPH radical scavenging } \\
\text { activity- } 42.02 \mathrm{~g} \text { ascorbic acid } \\
\text { equivalent/100 g (Benchikh et al., } \\
\text { 2020) }\end{array}$ & $\begin{array}{l}\text { ORAC - } 231.1 \mu \mathrm{M} \text { Trolox } \\
\text { equivalent/g (Neri-Numa et al., } \\
\text { 2018) }\end{array}$ & $\begin{array}{l}\text { DPPH radical scavenging } \\
\text { activity-12.2 mM Trolox } \\
\text { equivalent/g (Shen et al., 2019) }\end{array}$ \\
\hline $\begin{array}{l}\text { Aggregate formation in } \\
\text { acidic beverages }\end{array}$ & $\begin{array}{l}\text { Formation of aggregates in acidic } \\
\text { beverages with } \mathrm{pH} \text { around } \mathrm{pH} 3 \\
\text { (Zhang et al., 2020) }\end{array}$ & $\begin{array}{l}\text { Unstable in acidic beverages with } \\
\mathrm{pH} \text { around pH } 3 \text { (Buchweitz, 2016) }\end{array}$ & $\begin{array}{l}\text { No aggregate formation in acidic } \\
\text { solutions with } \mathrm{pH} \text { around } \mathrm{pH} 3 \\
\text { (Lakshan et al., 2019) }\end{array}$ \\
\hline
\end{tabular}

TABLE 3 | Application of blue pea flower anthocyanins as a natural colouring agent and their antioxidant/bioactivity.

\begin{tabular}{|c|c|c|}
\hline Product & Antioxidant/Bioactivity & References \\
\hline Functional beverage & $\begin{array}{l}\text { DPPH radical scavenging activity }-\mathrm{IC}_{50}- \\
247.6 \mu \mathrm{L} / \mathrm{mL} \\
\text { ABTS radical scavenging activity }-\mathrm{IC}_{50}- \\
35.8 \mu \mathrm{L} / \mathrm{mL} \\
\text { FRAP }-14.9 \mathrm{mg} \text { Trolox equivalent } / \mathrm{L} \\
\text { ORAC }-122.2 \mathrm{mg} \text { Trolox equivalent } / \mathrm{L}\end{array}$ & Lakshan et al., 2019 \\
\hline Functional drink powder & $\begin{array}{l}\text { Powder showing } 35-40 \% \text { scavenging in DPPH } \\
\text { radical scavenging activity }\end{array}$ & Marpaung et al., 2020 \\
\hline $\begin{array}{l}\text { Yoghurt (liquid skim milk, UHT milk, } \\
\text { pasteurised milk, UHT milk with }\end{array}$ & $\begin{array}{l}69.3-437.04 \text { ppm BHT equivalent in DPPH } \\
\text { radical scavenging activity }\end{array}$ & Sutakwa et al., 2021 \\
\hline
\end{tabular}

skim powder, and pasteurised milk

with skim powder)

Muffin

Bactericidal effect

Ab Rashid et al., 2021

acidic pH (Asadnejad et al., 2018). Contrastingly, blue pea flower anthocyanins showed stability in acidic $\mathrm{pH}$ under pasteurising conditions $\left(63^{\circ} \mathrm{C}\right.$ for $\left.30 \mathrm{~min}\right)$. Considering photostability, both phycocyanin and blue pea flower anthocyanins showed unstable nature against photo stress compared to genipin-derived pigments (Table 2). Therefore, special attention should be paid when using blue pea flower anthocyanins or genipin-derived pigments as a food colour to avoid photodegradation. Both phycocyanin and genipin-derived pigments were not stable in the acidic medium whereas the blue pea flower anthocyanins demonstrated high stability in acidic $\mathrm{pH}$ around $\mathrm{pH} 3$ to 5 . Products such as soft drinks, fruit drinks and jelly mainly contain artificial blue colourants belonging to this $\mathrm{pH}$ range (Asadnejad et al., 2018). This could be considered as a major advantage of using blue pea flower anthocyanins as a blue colourant over phycocyanin and genipin-derived pigments. All three blue colourants showed antioxidant activities, but a direct comparison cannot be made as they were determined by different antioxidant assays.

\section{ANTIOXIDANT ACTIVITY OF BLUE PEA FLOWER ANTHOCYANINS}

The antioxidant property is the ability to donate hydrogen atoms or electrons to free radicals and displace free radicals, thus preventing the damage caused by the free radicals (Tan and Lim, 2015). Anthocyanins demonstrate both in vivo and in vitro antioxidant activity (Migliorini et al., 2019; Vidana Gamage et al., 2021a). It is believed that blue pea flower anthocyanins could prevent cardiovascular and neurological diseases, cancer and diabetes, due to their antioxidant capabilities (Cazarolli et al., 2009; Shen et al., 2019). The toxicological safety of using blue pea flower extracts have been prove from some studies. An aqueous extract of blue pea flower petals showed no cytotoxicity in human fibroblast (IMR90) cells $\left(\mathrm{LC}_{50}>900 \mu \mathrm{g} / \mathrm{mL}\right.$ ) and showed a protective effect in human erythrocytes and inhibited the oxidation of pBR322 plasmid DNA (Mehmood et al., 2019; Escher et al., 2020b). A water extract of blue pea flower was nontoxic up to $625 \mu \mathrm{g} / \mathrm{mL}$ on RAW264.7 cells (Jeyaraj et al., 2021). 
The in vitro antioxidant properties displayed by water extracts of blue pea flower anthocyanins are shown in Table 1.

In one study, it was found that blue pea flower anthocyanin extract demonstrated significant antioxidant activity against $\mathrm{DPPH}$ and peroxyl radicals. Using $\mathrm{DPPH}$ assay, the $\mathrm{IC}_{50}$ (concentration of the antioxidants needed to decrease the initial free radical concentration by $50 \%$ ) of the blue pea flower anthocyanin extract $(0.47 \mathrm{mg} / \mathrm{mL})$ was significantly higher compared to that of ascorbic acid $(0.002 \mathrm{mg} / \mathrm{mL})$ (Phrueksanan et al., 2014). Similarly, in the study done by Zakaria et al. (2018), the anthocyanin extract from blue pea flower showed significant scavenging activity against DPPH and 2,2'-azino-bis (3-ethylbenzthiazoline-6-sulphonic acid (ABTS) radical scavenging assays (Table 1) and the $\mathrm{IC}_{50}$ values of the Trolox standard for both $\mathrm{DPPH}\left(\mathrm{IC}_{50}-\right.$ $3.32 \mu \mathrm{g} / \mathrm{mL}$ ) and ABTS assays ( $\mathrm{IC}_{50}-6.51 \mu \mathrm{g} / \mathrm{mL}$ ) were significantly lower compared to blue pea flower anthocyanin extract. This indicates that ascorbic acid and Trolox possess higher antioxidant activity compared with the blue pea flower anthocyanin extract.

Shen et al. (2019) also studied how the antioxidant property of blue pea flower anthocyanins prevent lipid oxidation. Lipid oxidation occurs when free radicals are available in the surrounding medium. A dose of $6 \mathrm{mg} / \mathrm{mL}$ blue pea flower anthocyanins extracted by distilled water was able to inhibit 7-keto cholesterol production in an emulsion of cholesterol and a free radical generator by $79.8 \%$ after $48 \mathrm{~h}$ of treatment (Shen et al., 2019). 7-keto cholesterol is formed from the cholesterol-free radical chain reaction through 7-hydroxyperoxycholesterol (7-OOH) dehydration or 7-hydroxycholesterol (7-OH) dehydrogenation (Xu et al., 2005). Therefore 7-keto cholesterol is used to measure the extent of lipid oxidation. Furthermore, the inhibition of lipid oxidation could be explained by the antioxidant activity of blue pea flower anthocyanins against free radicals. In another study, Jeyaraj et al. (2021) investigated the antioxidant activity of a water extract of blue pea petals, based on the ability of the blue pea flower extract to reduce the extent of $2,2^{\prime}$-azobis2-methyl-propanimidamide dihydrochloride (AAPH)-generated free radicals in RAW264.7 cells (mouse macrophage cells). It was found that the water extract with a concentration of $156.3 \mu \mathrm{g} / \mathrm{mL}$ blue pea flower extract demonstrated $75-80 \%$ inhibition against AAPH-generated free radical formation. Likewise, Phrueksanan et al. (2014) found that anthocyanin-rich extract of blue pea petals could protect erythrocytes from AAPH-induced haemolysis and oxidative damage. It was found that an anthocyanin-rich extract of blue pea petals $(400 \mu \mathrm{g} / \mathrm{mL})$ could reduce membrane lipid peroxidation, protein carbonyl group formation and prevent the reduction of glutathione concentration in $\mathrm{APPH}$ induced haemolysis (Phrueksanan et al., 2014). Furthermore, Zakaria et al. (2018) showed that a blue pea flower anthocyanin extract could protect human keratinocytes from $\mathrm{H}_{2} \mathrm{O}_{2}$-induced cytotoxicity and UV-induced mtDNA damage in human keratinocytes. The cellular antioxidant activity of blue pea flower extract is clearly demonstrated in these studies. Overall, the results of in vitro antioxidant assays should not be interpreted directly as the antioxidant property inside the body of a living being
(Gengatharan et al., 2015; Jeyaraj et al., 2020). Therefore, the antioxidant properties of blue pea flower anthocyanins in living systems should be investigated.

A major cause of non-communicable diseases is hyperglycaemia (Kim and Oh, 2013). Increased serum glucose levels after a meal could create several complications such as the production of mitochondrial reactive oxygen species (ROS) that can deplete antioxidant enzymes in serum. Studies have found that bioactive compounds such as anthocyanins could inhibit the action of carbohydrate digestive enzymes such as pancreatic $\alpha$-amylase and intestinal $\alpha$-glucosidase consequently reducing postprandial hyperglycaemia (McDougall et al., 2005). One study investigated the effect of ingestion of blue pea flower anthocyanins with or without sucrose on the glucose level and antioxidant capacity of the serum of humans. Eighteen healthy men between 18 and 40 years were selected and administered with different sucrose, water and blue pea flower anthocyanin extract treatments ( 1 or $2 \mathrm{~g}$ of blue pea flower anthocyanin extract $+400 \mathrm{~mL}$ water, $50 \mathrm{~g}$ sucrose $+400 \mathrm{~mL}$ water, 1 or $2 \mathrm{~g}$ of blue pea flower anthocyanin extract $+50 \mathrm{~g}$ sucrose $+400 \mathrm{~mL}$ water) after $12 \mathrm{~h}$ fasting period. Subjects who were administered with 1 and $2 \mathrm{~g}$ of blue pea flower anthocyanin extract with $400 \mathrm{~mL}$ of distilled water did not show any change in serum glucose level. It was observed that the subjects who ingested sucrose and water, had a rapid increase in plasma glucose level approximately by $75 \mathrm{mg} / \mathrm{dL}$ after $30 \mathrm{~min}$ of administration and fell back to normal level within $90 \mathrm{~min}$. Subjects who were administered with 1 or $2 \mathrm{~g}$ of blue pea flower anthocyanins with $50 \mathrm{~g}$ sucrose and $400 \mathrm{~mL}$ distilled water demonstrated an increase of serum glucose level only by $60 \mathrm{mg} / \mathrm{dL}$ within $30 \mathrm{~min}$ of ingestion but reduced significantly within $60 \mathrm{~min}$ and came to normal level in $90 \mathrm{~min}$. The postprandial plasma glucose concentration after 30 and $60 \mathrm{~min}$ of ingestion was significantly lower $(p<0.05)$ in the sucrose treatment with blue pea flower anthocyanins when compared to the sucrose treatment with water. Plasma insulin level increased in sucrose only treatment, but plasma insulin level did not change significantly with blue pea flower anthocyanins treatment. When sucrose was administered with blue pea flower anthocyanin extract the rise of plasma insulin level was significantly suppressed after $60 \mathrm{~min}$ of administration. The plasma antioxidant activity measured by FRAP and ABTS assays increased in all treatments, but subjects treated with blue pea flower anthocyanins with or without sucrose demonstrated a significantly higher plasma antioxidant activity. Ingestion of blue pea flower anthocyanin extract with or without sucrose showed reduced levels of plasma malondialdehyde (MDA) during the postprandial period that indicating a low level of lipid peroxidation. The plasma thiol concentration which is an indicator of plasma antioxidant defence mechanism reduced significantly within $30 \mathrm{~min}$ after ingestion of sucrose but administration of blue pea flower anthocyanin extract with or without sucrose increased the plasma thiol level indicating the strengthening of plasma antioxidant defence mechanism by blue pea flower anthocyanins (Chusak et al., 2018). Therefore, blue pea flower anthocyanins could reduce the serum glycaemic index, MDA level and increase the plasma antioxidant level during the postprandial period. The application of blue pea 
flowers anthocyanins in food as a food colourant or functional food ingredient may provide these health benefits to consumers.

\section{APPLICATIONS OF ANTHOCYANINS FROM BLUE PEA FLOWER}

Several studies have been done on the application of blue pea flower anthocyanins in many areas such as developing dyesensitised solar cells, pharmaceuticals etc. (Gokilamani et al., 2013; Nair et al., 2015). This review focuses on the current research on the application of anthocyanins from blue pea flowers in the food industry. Several studies have been carried out on the application of anthocyanins from blue pea flowers as a natural food colouring agent and those food demonstrate antioxidant activity and bio-preservative properties (Table 3). A study was carried out to develop a functional beverage using blue pea flower extract, stevia extract and lime. Out of the three formulations screened from preliminary tests, the most acceptable beverage selected from the sensory evaluation had the combination of the above three constituents in ratio 983.25:1.75:15 in manufacturing $1 \mathrm{~L}$ of the beverage. The beverage developed with the abovementioned combination of constituents were again tested with a sensory evaluation using a 9-point hedonic scale and for all the attributes (colour, sweetness, lime flavour, aroma and overall acceptability), a median score of 7 was obtained indicating moderate likeness. The antioxidant property of the functional beverage measured with DPPH, ABTS, FRAP and oxygen radical absorbance capacity (ORAC) assays are shown in Table 3 . The total phenolic content of the functional beverage was $85.5 \mathrm{mg}$ gallic acid equivalent/L. The beverage could be preserved at room temperature for 28 days without using any preservatives. When the $\mathrm{pH}$ of the beverage was adjusted between $\mathrm{pH} 2$ to $\mathrm{pH} 4$ to investigate the variation of colour, intense blue colour was observed between pH 3.5 and pH 4 (Lakshan et al., 2019). The reason for preserving the ability of blue pea flower extract incorporated functional beverage could be explained by the antimicrobial effect demonstrated by blue pea flower anthocyanins (Yanti et al., 2018). Therefore, blue pea flower anthocyanins can be used as a blue colourant in beverages having acidic $\mathrm{pH}$ between 3 to 4 . Similar work was done by Marpaung et al. (2020) in which a crystallised functional drink powder was prepared with an anthocyanin-rich blue pea flower extract and supersaturated sugar solution and citric acid. The best formulation was selected using an sensory evaluation with a 9-hedonic scale and the formulation with $58 \mathrm{~g}$ sucrose, $0.46 \mathrm{~g}$ citric acid and $80 \mathrm{~g}$ of blue pea flower extract in $250 \mathrm{~mL}$ distilled water was selected as the most acceptable drink for colour, aroma, taste and overall acceptability. The initial TAC of the powder was reduced by $50 \%$ within 28 days when stored at $27^{\circ} \mathrm{C}$ in dark and the halflife of the anthocyanins was further reduced at high storage temperature. Interestingly, the initial antioxidant capacity (35$40 \%$ scavenging in DPPH radical scavenging activity) of the powder remained almost unchanged during the storage period of four weeks. Therefore, it would be better to use anthocyanins from blue pea flowers as a natural colouring agent for functional beverages with shorter shelf life.
Sutakwa et al. (2021) investigated the antioxidant activity of yoghurts prepared with $10 \%(\mathrm{v} / \mathrm{v})$ blue pea flower anthocyanin extracts. Five different types of milk (liquid skim milk, ultra-heat treated (UHT) milk, pasteurised milk, UHT milk with skim milk, and pasteurised milk with skim milk) were used to prepare the yoghurt. The antioxidant activity of yoghurt samples coloured with blue pea flower anthocyanins was significantly higher compared to the control samples and yoghurts prepared with skim milk showed the highest antioxidant activity (437.04 ppm measured by DPPH radical scavenging activity calculated using a standard linear equation with the butylated hydroxytoluene (BHT) as a standard curve). These studies evidently showed that the antioxidant activity of food increases when anthocyanins from blue pea flowers are used as a food colourant.

Thanh et al. (2020) investigated the application of blue pea flower anthocyanin extract in cupcakes. After baking at $170^{\circ} \mathrm{C}$ for $20 \mathrm{~min}$, only $41.8 \%$ of the initial anthocyanin content was retained in the cupcake. The blue colour of the blue pea flower anthocyanin extract turned to greenish colour due to the $\mathrm{pH}$ change that happened in the dough. However, in the sensory evaluation, it was found that the aroma, colour, flavour and overall acceptability of the cupcakes with blue pea flower anthocyanins were higher compared with the control samples. The reason for the lower retention percentage could be attributed to the thermal deterioration of anthocyanins at high baking temperatures.

Studies show that the protection of anthocyanins with wall material by microencapsulation could enhance the stability of anthocyanins (Marsin et al., 2020). Therefore, the application of encapsulated blue pea flower anthocyanins in functional food provides a solution to enhance their stability in functional food. The application of encapsulated blue pea flower anthocyanins as a food colourant in baked food products (muffins) was studied (Ab Rashid et al., 2021). This study reported that the bacterial load on muffins with blue pea flower anthocyanins was significantly lower compared with the control sample. Therefore, blue pea flower anthocyanins have played two roles: one as a natural colouring agent and the other as a biopreservative in this baked food product. This bio-preservative action of blue pea flower anthocyanins is supported by the study of Leong et al. (2017) where the anthocyanins from blue pea flower showed anti-fungal properties against the foodborne Penicillium expansum conidia. Nikijuluw and Andarwulan (2013) applied blue pea flower anthocyanin extracts to colour a yoghurt drink and rice. When the blue pea flower anthocyanin extract was added to yoghurt drink $(\mathrm{pH} 4.5)$ at a concentration of $3.37 \times 10^{-5} \mathrm{mg}$ anthocyanin $/ \mathrm{mL}$ and rice $(\mathrm{pH} 7)$ at a concentration of $1.6 \times 10^{-4} \mathrm{mg}$ anthocyanin/g, the yoghurt drink has a purplish-blue colour and the rice had a dark blue colour. In this study, Brilliant Blue, a synthetic colourant was also added to yoghurt drink at a concentration of $3.13 \times 10^{-4} \mathrm{mg} / \mathrm{mL}$ and to rice at a concentration of $3.2 \times 10^{-4} \mathrm{mg} / \mathrm{g}$ and the colour of yoghurt drink and rice were green-blue and light blue, respectively (Nikijuluw and Andarwulan, 2013). Even though this study compared the stability of blue pea flower anthocyanin extract and Brilliant Blue, they did not investigate the stability of the colours after applying them in the food systems. It would be 
useful if a comparison was done in food systems to determine the colour stability and the bioactivity after adding the colourants.

The use of a colourimetric indicator in intelligent packaging has been used as a freshness indicator of perishable food products such as fish and meat. Colourimetric indicators provide real-time information on the freshness of the food material based on the $\mathrm{pH}$ dependant colour change (Priyadarshi et al., 2021). Microbial action on fish and meat produces chemical compounds such as amines that cause a pH change (Fletcher et al., 2018). Generally used chemical reagents as colourimetric indicators in intelligent packaging contain synthetic chemical compounds such as bromophenol blue and chlorophenol red are not safe to use for food packaging due to the possibility of migration of these compounds to food and their possible harmful effects on human health (Zhang et al., 2014; Poyatos-Racionero et al., 2018). Therefore, the invention of safer alternative reagents for this purpose is desired. The $\mathrm{pH}$ dependant colour variation of anthocyanins could be used to develop these kinds of intelligent packaging systems.

Several studies have been done on the application of anthocyanins from blue pea flowers as a colour indicator in intelligent packaging (Ahmad et al., 2020; Netramai et al., 2020; Salacheep et al., 2020; Singh et al., 2021). One study used anthocyanins from blue pea flowers in an intelligent packaging system incorporated in a film made with distilled water and $5 \%(\mathrm{w} / \mathrm{v})$ sago powder (Ahmad et al., 2020). It was observed the colour of the packaging film changed from blue to green in $24 \mathrm{~h}$ when the chicken sample was kept at room temperature but the chicken sample kept in frozen condition did not alter the colour of the indicator even after $48 \mathrm{~h}$ (Ahmad et al., 2020). This study reported that the colour change of anthocyanin extract from blue pea flower at varying $\mathrm{pH}$ was more distinct compared with those of anthocyanin extracts from hibiscus, purple sweet potato and red yeast rice. Another study used anthocyanin extract from blue pea flowers as a colour indicator in gelatin film (Rawdkuen et al., 2020). A packaging film was made with gelatin, glycerol and anthocyanin extract from blue pea flower. The initial $\mathrm{pH}$ of gelatin film was 6 and the colour was blue. When $\mathrm{pH}$ reduced to 4 , the film turned to violet and when $\mathrm{pH}$ increased to $\mathrm{pH} 8$ the film turned to green. The incorporation of anthocyanin extract from the blue pea flower slightly reduced the tensile strength and water vapour permeability of the gelatin film but significantly increased the antioxidant capacity of the gelatin film (Rawdkuen et al., 2020). Another study used a gelatin film with blue pea flower anthocyanins as a colour indicating package to monitor fish freshness. Initially, the packaging film was dark bluish-purple at the beginning and turned to bluish-green when the fish was kept at room temperature for $24 \mathrm{~h}$ (Salacheep et al., 2020). Another study used anthocyanin extract from blue pea flowers in a freshness monitoring packaging for prawns made with starch and $\mathrm{TiO}_{2}$. The colour of the colour indicator changed from pink to green when prawns were stored at $4^{\circ} \mathrm{C}$ for 6 days (Mary et al., 2020). Similarly, Wu et al. (2021) developed an intelligent packaging film using gellan gum adding blue pea flower anthocyanin extract to monitor the freshness of shrimp.
The colour of the film changed distinctly from blue to green when the shrimp were kept at $25^{\circ} \mathrm{C}$ for $24 \mathrm{~h}$. The $\mathrm{pH}$ of shrimp changed from $\mathrm{pH} 5$ to $\mathrm{pH} 8$ within $24 \mathrm{~h}$ due to the production of nitrogenous compounds produced during spoilage. Therefore, blue pea flower anthocyanin extracts can be used to develop intelligent packaging systems to monitor the freshness of seafood as well.

In addition to freshness monitoring systems of animal products, Singh et al. (2021) used anthocyanins of blue pea flowers to develop an intelligent film to monitor the freshness of beverages. Anthocyanin extracts from Clitoria ternatea and Carissa carandas were incorporated into chitosanpoly (vinyl alcohol) films separately and used to monitor the freshness of milk and fresh orange juice. It was observed that incorporation of anthocyanin extracts did not significantly alter the physical properties of the film and the film with Clitoria ternatea anthocyanin extract was more $\mathrm{pH}$-sensitive in terms of colour change compared with the film with the anthocyanin extract of Carissa carandas. The film with Clitoria ternatea anthocyanin extract showed a distinct change in colour for both milk and juice stored at $25^{\circ} \mathrm{C}$ after $72 \mathrm{~h}$ where the $\mathrm{pH}$ of milk changed from 6.2 to 4.1 and the $\mathrm{pH}$ of juice changed from 4.2 to 3.4 (Singh et al., 2021). Therefore, anthocyanins from blue pea flowers could be considered as a promising colour indicator for intelligent packaging.

\section{CONCLUSION AND FUTURE PERSPECTIVE OF RESEARCH}

Clitoria ternatea or blue pea flower is an edible flower with medicinal and ornamental value. The blue pea flower is a rich source of polyacylated anthocyanins demonstrating higher stability than non-acylated anthocyanins. Blue pea flower anthocyanins demonstrate an intense and stable blue colour in acidic medium which facilitate their application in acidic food systems as a blue food colouring agent. The cellular and in vitro antioxidant activities of blue pea flower anthocyanins show their potential application in functional foods. Several studies have been conducted on investigating the application of blue pea flower anthocyanins as a food colourant in bakery products, yoghurt and functional beverages. Further research should be carried out on the application of blue pea flower anthocyanins in other food systems. Studies have shown antioxidant and antimicrobial activities of blue pea flower anthocyanins in different applications. Further research could be carried out to investigate the bioavailability and other functional properties of blue pea flower anthocyanins. Since there are limited blue food colourants available, blue pea flower anthocyanins will be a good alternative to be used as a natural blue food colouring agent.

\section{AUTHOR CONTRIBUTIONS}

GCVG: responsible for writing and editing the manuscript. YYL: responsible for reviewing and editing the manuscript. 
WSC: responsible for the conceptualisation, funding acquisition, and reviewing and editing of the manuscript. All authors contributed to the article and approved the submitted version.

\section{REFERENCES}

Ab Rashid, S., Tong, W. Y., Leong, C. R., Ghazali, N. M. A., Abu Taher, M., Ahmad, N., et al. (2021). Anthocyanin microcapsule from Clitoria ternatea: Potential bio-preservative and blue colorant for baked food products. Arab. J. Sci. Eng. 46, 65-72. doi: 10.1007/s13369-020-04716-y

Abidin, Z. H. Z., Manah, N. S. A., Hadi, A. N., Saugi, N. S., Fuad, F. A., Mazni, N. A., et al. (2019). The colour stability of natural blue dye extracted from Clitoria ternatea L. in poly(acrylamide-co-acrylic acid) coating film. Pigment Resin Technol. 48, 265-271. doi: 10.1108/prt-12-2017-0106

Ahmad, A. N., Lim, S. A., and Navaranjan, N. (2020). Development of sago (Metroxylon sagu)-based colorimetric indicator incorporated with butterfly pea (Clitoria ternatea) anthocyanin for intelligent food packaging. J. Food Saf. 40:9. doi: $10.1111 /$ jfs. 12807

Aprodu, I., Milea, Ș. A., Enachi, E., Râpeanu, G., Bahrim, G. E., and Stǎnciuc, N. (2020). Thermal degradation kinetics of anthocyanins extracted from purple maize flour extract and the effect of heating on selected biological functionality. Foods 9:1593. doi: 10.3390/foods9111593

Asadnejad, S., Nabizadeh, R., Nazarinia, A., Jahed, G. R., and Alimohammadi, M. (2018). Data on prevalence of additive colors in local food and beverage products, Tehran, Iran. Data Brief 19, 2104-2108. doi: 10.1016/j.dib.2018.07. 001

Baskaran, A., Mudalib, S. K. A., and Izirwan, I. (2019). Optimization of aqueous extraction of blue dye from butterfly pea flower. J. Phys. 1358:012001. doi: 10.1088/1742-6596/1358/1/012001

Benchikh, Y., Filali, A., and Rebai, S. (2020). Modeling and optimizing the phycocyanins extraction from Arthrospira platensis (Spirulina) algae and preliminary supplementation assays in soft beverage as natural colorants and antioxidants. J. Food Process. Preserv. 45:e15170. doi: 10.1111/jfpp.1 5170

Bridle, P., and Timberlake, C. (1997). Anthocyanins as natural food coloursselected aspects. Food Chem. 58, 103-109. doi: 10.1016/S0308-8146(96)00 222-1

Buchweitz, M. (2016). "Natural solutions for blue colors in food," in The Handbook on Natural Pigments in Food and Beverages, eds R. Carle and R. M. Schweiggert (Oxford: Woodhead Publishing), 355-384. doi: 10.1016/B978-0-08-100371-8. 00017-8

Buchweitz, M., Nagel, A., Carle, R., and Kammerer, D. R. (2012). Characterisation of sugar beet pectin fractions providing enhanced stability of anthocyaninbased natural blue food colourants. Food Chem. 132, 1971-1979. doi: 10.1016/j. foodchem.2011.12.034

Cazarolli, L. H., Folador, P., Pizzolatti, M. G., and Silva, F. R. M. B. (2009). Signaling pathways of kaempferol-3-neohesperidoside in glycogen synthesis in rat soleus muscle. Biochimie 91, 843-849. doi: 10.1016/j.biochi.2009.04.004

Chaiklahan, R., Chirasuwan, N., and Bunnag, B. (2012). Stability of phycocyanin extracted from Spirulina sp.: influence of temperature, $\mathrm{pH}$ and preservatives. Process Biochem. 47, 659-664. doi: 10.1016/j.procbio.2012.0 1.010

Chaiklahan, R., Chirasuwan, N., Loha, V., Tia, S., and Bunnag, B. (2018). Stepwise extraction of high-value chemicals from Arthrospira (Spirulina) and an economic feasibility study. Biotechnol. Rep. 20:e00280. doi: 10.1016/j.btre. 2018.e00280

Chandrasekhar, J., Madhusudhan, M. C., and Raghavarao, K. S. M. S. (2012). Extraction of anthocyanins from red cabbage and purification using adsorption. Food Bioprod. Process. 90, 615-623. doi: 10.1016/j.fbp.2012.07.004

Charurungsipong, P., Tangduangdee, C., Amornraksa, S., Asavasanti, S., and Lin, J. (2020). Improvement of anthocyanin stability in butterfly pea flower extract by co-pigmentation with catechin. E3S web of conferences, 2020. EDP Sci. 141:03008. doi: 10.1051/e3sconf/202014103008

Chemat, F., Abert Vian, M., Ravi, H. K., Khadhraoui, B., Hilali, S., Perino, S., et al. (2019). Review of alternative solvents for green extraction of food and natural

\section{FUNDING}

This work was funded by the School of Science, Monash University, Malaysia.

products: panorama, principles, applications and prospects. Molecules 24:3007. doi: 10.3390/molecules24163007

Chemat, F., Huma, Z. E., and Khan, M. K. (2011). Applications of ultrasound in food technology: processing, preservation and extraction. Ultrason. Sonochem. 18, 813-835. doi: 10.1016/j.ultsonch.2010.11.023

Choo, W. S. (2019). "Fruit pigment changes during ripening," in The Encyclopedia of Food Chemistry, eds L. Melton, F. Shahidi, and P. Varelis (Elsevier: The Netherlands), 17-123.

Chusak, C., Thilavech, T., Henry, C. J., and Adisakwattana, S. (2018). Acute effect of Clitoria ternatea flower beverage on glycemic response and antioxidant capacity in healthy subjects: a randomized crossover trial. BMC Complement. Altern. Med. 18:11. doi: 10.1186/s12906-017-2075-7

Collings, D. A. (2019). Anthocyanin in the vacuole of red onion epidermal cells quenches other fluorescent molecules. Plants 8:596. doi: 10.3390/plants812 0596

Daniel, R. M., and Danson, M. J. (2013). Temperature and the catalytic activity of enzymes: a fresh understanding. FEBS Lett. 587, 2738-2743. doi: 10.1016/j. febslet.2013.06.027

Dilrukshi, P. G. T., Munasinghe, H., Silva, A. B. G., and De Silva, P. G. S. M. (2019). Identification of synthetic food colours in selected confectioneries and beverages in jaffna District, Sri Lanka. J. Food Qual. 2019:453169. doi: 10.1155/ 2019/7453169

Escher, G. B., Marques, M. B., do Carmo, M. A. V., Azevedo, L., Furtado, M. M., Sant'Ana, A. S., et al. (2020b). Clitoria ternatea L. Petal bioactive compounds display antioxidant, antihemolytic and antihypertensive effects, inhibit $\alpha$ amylase and $\alpha$-glucosidase activities and reduce human LDL cholesterol and DNA induced oxidation. Food Res. Int. 128:108763. doi: 10.1016/j.foodres.2019. 108763

Escher, G. B., Wen, M., Zhang, L., Rosso, N. D., and Granato, D. (2020a). Phenolic composition by UHPLC-Q-TOF-MS/MS and stability of anthocyanins from Clitoria ternatea L. (butterfly pea) blue petals. Food Chem. 331:127341. doi: 10.1016/j.foodchem.2020.127341

FDA (2015). Summary of Color Additives for Use in the United States in Foods, Drugs, Cosmetics, and Medical Devices. Silver Spring, MD: FDA.

FDA (2018). Q3C-Tables and List Guidance for Industry. Available online at: www.fda.gov/regulatory-information/search-fda-guidance-documents/q3ctables-and-list-rev-4 (accessed September 8, 2021)

Feketea, G., and Tsabouri, S. (2017). Common food colorants and allergic reactions in children: myth or reality? Food Chem. 230, 578-588. doi: 10.1016/j.foodchem. 2017.03.043

Fletcher, B., Mullane, K., Platts, P., Todd, E., Power, A., Roberts, J., et al. (2018). Advances in meat spoilage detection: a short focus on rapid methods and technologies. CYTA J. Food 16, 1037-1044. doi: 10.1080/19476337.2018. 1525432

Garcia, C., and Blesso, C. N. (2021). Antioxidant properties of anthocyanins and their mechanism of action in atherosclerosis. Free Radic. Biol. Med. 172, 152-166. doi: 10.1016/j.freeradbiomed.2021.05.040

Gengatharan, A., Dykes, G. A., and Choo, W. S. (2015). Betalains: natural plant pigments with potential application in functional foods. LWT Food Sci. Technol. 64, 645-649. doi: 10.1016/j.lwt.2015.06.052

Gokilamani, N., Muthukumarasamy, N., Thambidurai, M., Ranjitha, A., and Velauthapillai, D. (2013). Utilization of natural anthocyanin pigments as photosensitizers for dye-sensitized solar cells. J. Sol Gel Sci. Technol. 66, 212219. doi: 10.1007/s10971-013-2994-9

Gustiningtyas, A., Setyaningsih, I., Hardiningtyas, S. D., and Susila, A. A. R. (2020). Improvement stability of phycocyanin from Spirulina platensis encapsulated by water soluble chitosan nanoparticles. IOP Conf. Ser. 414:012005. doi: 10.1088/ 1755-1315/414/1/012005

Gwee, X. F., and Chong, F. C. (2015). Ultrasonic extraction of anthocyanin from Clitoria ternatea flowers using response surface methodology. Nat. Prod. Res. 29, 1485-1487. doi: 10.1080/14786419.2015.1027892 
Havananda, T., and Luengwilai, K. (2019). Variation in floral antioxidant activities and phytochemical properties among butterfly pea (Clitoria ternatea L.) germplasm. Genet. Resour. Crop Evol. 66, 645-658. doi: 10.1007/s10722-01800738-6

Honda, T., and Saito, N. (2002). Recent progress in the chemistry of polyacylated anthocyanins as flower color pigments. Heterocycles 56, 633-692.

Jaafar, N. F., Ramli, M. E., and Salleh, R. M. (2020). Optimum extraction condition of Clitorea ternatea flower on antioxidant activities, total phenolic, total flavonoid and total anthocyanin contents. Trop. Life Sci. Res. 31, 1-17. doi: $10.21315 /$ tlsr2020.31.2.1

Jeyaraj, E. J., Lim, Y. Y., and Choo, W. S. (2020). Extraction methods of butterfly pea (Clitoria ternatea) flower and biological activities of its phytochemicals. J. Food Sci. Technol. 58, 2054-2067. doi: 10.1007/s13197-020-04745-3

Jeyaraj, E. J., Lim, Y. Y., and Choo, W. S. (2021). Effect of organic solvents and water extraction on the phytochemical profile and antioxidant activity of Clitoria ternatea flowers. ACS Food Sci. Technol 1, 1567-1577. doi: 10.1021/ acsfoodscitech.1c00168

Jing, P., and Giusti, M. M. (2007). Effects of extraction conditions on improving the yield and quality of an anthocyanin-rich purple corn (Zea mays L.) color extract. J. Food Sci. 72, C363-C368. doi: 10.1111/j.1750-3841.2007.0 0441.x

Kang, H. J., Ko, M. J., and Chung, M. S. (2021). Anthocyanin structure and pH dependent extraction characteristics from blueberries (Vaccinium corymbosum) and chokeberries (Aronia melanocarpa) in Subcritical Water State. Foods 10:527. doi: $10.3390 /$ foods 10030527

Kazuma, K., Kogawa, K., Noda, N., Kato, N., and Suzuki, M. (2004). Identification of delphinidin 3-O-(6" $6^{\prime \prime} \mathrm{O}$-malonyl)-beta-glucoside-3'-O-betaglucoside, a postulated intermediate in the biosynthesis of ternatin $\mathrm{C} 5$ in the blue petals of Clitoria ternatea (butterfly pea). Chem. Biodivers. 1, 1762-1770. doi: $10.1002 /$ cbdv. 200490132

Khoo, H. E., Azlan, A., Tang, S. T., and Lim, S. M. (2017). Anthocyanidins and anthocyanins: colored pigments as food, pharmaceutical ingredients, and the potential health benefits. Food Nutr. Res. 61:1361779. doi: 10.1080/16546628. 2017.1361779

Kim, H. C., and Oh, S. M. (2013). Noncommunicable diseases: current status of major modifiable risk factors in Korea. J. Prev. Med. Public Health 46:165.

Kogawa, K., Kazuma, K., Kato, N., Noda, N., and Suzuki, M. (2007a). Biosynthesis of malonylated flavonoid glycosides on the basis of malonyltransferase activity in the petals of Clitoria ternatea. J. Plant Physiol. 164, 886-894. doi: 10.1016/j. jplph.2006.05.006

Kogawa, K., Kato, N., Kazuma, K., Noda, N., and Suzuki, M. (2007b). Purification and characterization of UDP-glucose: anthocyanin $3^{\prime}, 5^{\prime}$-O-glucosyltransferase from Clitoria ternatea. Planta 226, 1501-1509. doi: 10.1007/s00425-007-0 584-1

Kosai, P., Sirisidthi, K., Jiraungkoorskul, K., and Jiraungkoorskul, W. (2015). Review on ethnomedicinal uses of memory boosting herb, butterfly pea, Clitoria ternatea. J. Nat. Remedies 15, 71-76.

Lakshan, S. A. T., Jayanath, N. Y., Abeysekera, W. P. K. M., and Abeysekera, W. K. S. M. (2019). A commercial potential blue pea (Clitoria ternatea L.) flower extract incorporated beverage having functional properties. Evid. Based Complement. Alternat. Med. 2019:2916914. doi: 10.1155/2019/291 6914

Landim Neves, M. I., Silva, E. K., and Meireles, M. A. A. (2021). Natural blue food colorants: consumer acceptance, current alternatives, trends, challenges, and future strategies. Trends Food Sci. Technol. 112, 163-173. doi: 10.1016/j.tifs. 2021.03.023

Lee, P. M., Abdullah, R., and Hung, L. K. (2011). "Thermal degradation of blue anthocyanin extract of Clitoria ternatea flower," in Biotechnology and Food Service, ed. L. Xuan (Singaore: International Assocation of Computer Science \& Information Technology Press-IACSIT Press), 49-53.

Leong, C. R., Kamarul Azizi, M. A., Taher, M. A., Wahidin, S., Lee, K. C., Tan, W. N., et al. (2017). Anthocyanins from Clitoria ternatea attenuate food-borne Penicillium expansum and its potential application as food biopreservative. Nat. Prod. Sci. 23, 125-131. doi: 10.20307/nps.2017.23.2.125

Li, N., Li, J., Hao, J. Y., Zhang, M., Yin, J. J., Geng, J. T., et al. (2019). Bilberry anthocyanin improves the serum cholesterol in aging perimenopausal rats via the estrogen receptor signaling pathway. Food Funct. 10, 3430-3438. doi: 10. 1039/c9fo00639g
Lin, W. S., He, P. H., Chau, C. F., Liou, B. K., Li, S., and Pan, M. H. (2018). The feasibility study of natural pigments as food colorants and seasonings pigments safety on dried tofu coloring. Food Sci. Hum. Wellness 7, 220-228. doi: 10.1016/j.fshw.2018.09.002

Liu, S., Fu, Y., and Nian, S. (2014). Buffering colour fluctuation of purple sweet potato anthocyanins to acidity variation by surfactants. Food Chem. 162, 16-21. doi: 10.1016/j.foodchem.2014.04.029

Liu, Y., Tikunov, Y., Schouten, R. E., Marcelis, L. F. M., Visser, R. G. F., and Bovy, A. (2018). Anthocyanin biosynthesis and degradation mechanisms in solanaceous vegetables: a Review. Front. Chem. 6:52. doi: 10.3389/fchem.2018.00052

Loypimai, P., Moongngarm, A., and Chottanom, P. (2016). Thermal and $\mathrm{pH}$ degradation kinetics of anthocyanins in natural food colorant prepared from black rice bran. J. Food Sci. Technol. 53, 461-470. doi: 10.1007/s13197-0152002-1

Lu, C., Li, Y., Cui, Y., Ren, J., Qi, F., Qu, J., et al. (2021). Isolation and functional analysis of genes involved in polyacylated anthocyanin biosynthesis in blue Senecio cruentus. Front. Plant Sci. 12:640746. doi: 10.3389/fpls.2021.64 0746

Mahmad, N., and Taha, R. M. (2018). Effects of $\mathrm{pH}, \mathrm{UV}-\mathrm{B}$ radiation and $\mathrm{NaCl}$ on anthocyanin stability from vivid blue petals of Clitoria ternatea L., a potential natural colourant from legume crop. Pigment Resin Technol. 47, 507-510. doi: 10.1108/prt-11-2016-0106

Marpaung, A. M., Andarwulan, N., Hariyadi, P., and Faridah, D. N. (2017). The colour degradation of anthocyanin-rich extract from butterfly pea (Clitoria ternatea L.) petal in various solvents at pH 7. Nat. Prod. Res. 31, 2273-2280. doi: 10.1080/14786419.2017.1303689

Marpaung, A. M., Andarwulan, N., Hariyadi, P., and Faridah, D. N. (2019). The difference in colour shifting of Clitoria ternatea L. Flower extract at $\mathrm{pH} 1$, 4, and 7 during storage. Curr. Nutr. Food Sci. 15, 694-699. doi: 10.2174/ 1573401314666180503152636

Marpaung, A. M., Lee, M., and Kartawiria, I. S. (2020). The development of butterfly pea (Clitoria ternatea) flower powder drink by co-crystallization. Indone Food Sci. Technol. J. 3, 34-37. doi: 10.22437/ifstj.v3i2.10185

Marsin, A. M., Jusoh, Y. M. M., Abang, D. N., Zaidel, Z. H., Yusof, A. H. M., and Muhamad, I. I. (2020). Microwave-assisted encapsulation of blue pea flower (Clitoria ternatea) colourant: maltodextrin concentration, power, and time. Chem. Eng. Trans. 78, 199-204. doi: 10.3303/CET2078034

Mary, S. K., Koshy, R. R., Daniel, J., Koshy, J. T., Pothen, L. A., and Thomas, S. (2020). Development of starch based intelligent films by incorporating anthocyanins of butterfly pea flower and $\mathrm{TiO}_{2}$ and their applicability as freshness sensors for prawns during storage. RSC Adv. 10, 39822-39830. doi: 10.1039/D0RA05986B

Matsufuji, H., Kido, H., Misawa, H., Yaguchi, J., Otsuki, T., Chino, M., et al. (2007). Stability to light, heat, and hydrogen peroxide at different $\mathrm{pH}$ values and $\mathrm{DPPH}$ radical scavenging activity of acylated anthocyanins from red radish extract. J. Agric. Food Chem. 55, 3692-3701. doi: 10.1021/jf063598o

McDougall, G. J., Shpiro, F., Dobson, P., Smith, P., Blake, A., and Stewart, D. (2005). Different polyphenolic components of soft fruits inhibit $\alpha$-amylase and $\alpha$-glucosidase. J. Agric. Food Chem. 53, 2760-2766. doi: 10.1021/jf0489926

Mehmood, A., Ishaq, M., Zhao, L., Yaqoob, S., Safdar, B., Nadeem, M., et al. (2019). Impact of ultrasound and conventional extraction techniques on bioactive compounds and biological activities of blue butterfly pea flower (Clitoria ternatea L.). Ultrason. Sonochem. 51, 12-19. doi: 10.1016/j.ultsonch.2018.10. 013

Migliorini, A. A., Piroski, C. S., Daniel, T. G., Cruz, T. M., Escher, G. B., Vieira do Carmo, M. A., et al. (2019). Red chicory (Cichorium intybus) extract rich in anthocyanins: chemical stability, antioxidant activity, and antiproliferative activity in vitro. J. Food Sci. 84, 990-1001. doi: 10.1111/1750-3841.14506

Nair, V., Bang, W. Y., Schreckinger, E., Andarwulan, N., and Cisneros-Zevallos, L. (2015). Protective role of ternatin anthocyanins and quercetin glycosides from butterfly pea (Clitoria ternatea Leguminosae) blue flower petals against lipopolysaccharide (LPS)-induced inflammation in macrophage cells. J. Agric. Food Chem. 63:6355. doi: 10.1021/acs.jafc.5b00928

Neri-Numa, I. A., Angolini, C. F. F., Bicas, J. L., Ruiz, A., and Pastore, G. M. (2018). Iridoid blue-based pigments of Genipa americana L. (Rubiaceae) extract: influence of $\mathrm{pH}$ and temperature on color stability and antioxidant capacity during in vitro simulated digestion. Food Chem. 263, 300-306. doi: 10.1016/j. foodchem.2018.05.001 
Netramai, S., Kijchavengkul, T., Kham-Ngam, C., Sirinupong, P., Kwanmuang, S., Samsudin, H., et al. (2020). "Development of colorimetric film with butterfly pea (Clitoria ternatea L.) extract for application in intelligent packaging," in Proceedings of the 22 ${ }^{\text {nd }}$ Food Innovation Asia Conference 2020 (FIAC 2020), (Bangkok).

Nikijuluw, C., and Andarwulan, N. (2013). Color Characteristic of Butterfly Pea (Clitoria ternatea L.) Anthocyanin Extracts and Brilliant Blue. Bogor: Bogor Agriculture University.

Oguis, G. K., Gilding, E. K., Jackson, M. A., and Craik, D. J. (2019). Butterfly pea (Clitoria ternatea), a cyclotide-bearing plant with applications in agriculture and medicine. Front. Plant. Sci. 10:23. doi: 10.3389/fpls.2019.0 0645

Paik, Y. S., Lee, C. M., Cho, M. H., and Hahn, T. R. (2001). Physical stability of the blue pigments formed from geniposide of gardenia fruits: effects of $\mathrm{pH}$, temperature, and light. J. Agric. Food Chem. 49, 430-432. doi: 10.1021/jf000 $978 \mathrm{f}$

Pasukamonset, P., Kwon, O., and Adisakwattana, S. (2017). Oxidative stability of cooked pork patties incorporated with Clitoria ternatea extract (Blue pea flower petal) during refrigerated storage. J. Food Process Preserv. 41:10. doi: 10.1111/jfpp.12751

Patel, A., Pawar, R., Mishra, S., Sonawane, S., and Ghosh, P. K. (2004). Kinetic studies on thermal denaturation of C-phycocyanin. Ind. J. Biochem. Biophys. 41, 254-257.

Pham, T. N., Nguyen, D. C., Lam, T. D., Van Thinh, P., Le, X. T., Nguyen, D. V. V., et al. (2019). "Extraction of anthocyanins from Butterfly pea (Clitoria ternatea L. Flowers) in Southern Vietnam: response surface modeling for optimization of the operation conditions," in Proceedings of the 2018 the $6^{\text {th }}$ International Conference on Mechanical Engineering, IOP Conference Series: Materials Science and Civil Engineering, (Bristol: Iop Publishing Ltd).

Phrueksanan, W., Yibchok-anun, S., and Adisakwattana, S. (2014). Protection of Clitoria ternatea flower petal extract against free radical-induced hemolysis and oxidative damage in canine erythrocytes. Res. Vet. Sci. 97, 357-363. doi: 10.1016/j.rvsc.2014.08.010

Poyatos-Racionero, E., Ros-Lis, J. V., Vivancos, J. L., and Martínez-Máñez, R. (2018). Recent advances on intelligent packaging as tools to reduce food waste. J. Clean Prod. 172, 3398-3409. doi: 10.1016/j.jclepro.2017.11.075

Priyadarshi, R., Ezati, P., and Rhim, J. W. (2021). Recent advances in intelligent food packaging applications using natural food colorants. ACS Food Sci. Technol. 1, 124-138. doi: 10.1021/acsfoodscitech.0c00039

Ranieri, M. L., Huck, J. R., Sonnen, M., Barbano, D. M., and Boor, K. J. (2009). High temperature, short time pasteurization temperatures inversely affect bacterial numbers during refrigerated storage of pasteurized fluid milk. J. Dairy Sci. 92, 4823-4832. doi: 10.3168/jds.2009-2144

Rawdkuen, S., Faseha, A., Benjakul, S., and Kaewprachu, P. (2020). Application of anthocyanin as a color indicator in gelatin films. Food Biosci. 36:100603. doi: 10.1016/j.fbio.2020.100603

Rocha, R., Pinela, J., Abreu, R. M. V., Añibarro-Ortega, M., Pires, T. C. S. P., Saldanha, A. L., et al. (2020). Extraction of anthocyanins from red raspberry for natural food colorants development: processes optimization and in vitro bioactivity. Processes 8:1447. doi: 10.3390/pr8111447

Salacheep, S., Kasemsiri, P., Pongsa, U., Okhawilai, M., Chindaprasirt, P., and Hiziroglu, S. (2020). Optimization of ultrasound-assisted extraction of anthocyanins and bioactive compounds from butterfly pea petals using Taguchi method and Grey relational analysis. J. Food Sci. Technol. 57, 3720-3730. doi: 10.1007/s13197-020-04404-7

Salehi, B., Sharifi-Rad, J., Cappellini, F., Reiner, Ž, Zorzan, D., Imran, M., et al. (2020). The therapeutic potential of anthocyanins: current approaches based on their molecular mechanism of action. Front. Pharmacol. 11:1300. doi: 10.3389/ fphar.2020.01300

Saptarini, N. M., and Suryasaputra, D. (2018). Total anthocyanins content in various extract of butterfly pea (Clitoria ternatea linn) flower. Res. J. Pharm. Biol. Chem. Sci. 9, 185-188.

Sen, T., Barrow, C. J., and Deshmukh, S. K. (2019). Microbial pigments in the food industry-challenges and the way forward. Front. Nutr. 6:7. doi: 10.3389/fnut. 2019.00007

Shen, Y., Ardoin, R., Osorio, L. F., Cardona, J., López Prado, A. S., Osorio, L. F., et al. (2019). Effects of different solvents on total phenolic and total anthocyanin contents of Clitoria ternatea L. petal and their anti-cholesterol oxidation capabilities. Int. J. Food Sci. Technol. 54:424431. doi: 10.1111/ijfs. 13953

Singh, S., Nwabor, O. F., Syukri, D. M., and Voravuthikunchai, S. P. (2021). Chitosan-poly(vinyl alcohol) intelligent films fortified with anthocyanins isolated from Clitoria ternatea and Carissa carandas for monitoring beverage freshness. Int. J. Biol. Macromol. 182, 1015-1025. doi: 10.1016/j.ijbiomac.2021. 04.027

Sutakwa, A., Nadia, L. S., and Suharman, S. (2021). Addition of blue pea flower (Clitoria ternatea L.) extract increase antioxidant activity in yogurt from various types of milk. J. Agercolere 3, 31-37. doi: 10.37195/jac.v3i 1.123

Syafa'atullah, A. Q., Amira, A., Hidayati, S., and Mahfud, M. (2020). Anthocyanin from butterfly pea flowers (Clitoria ternatea) by ultrasonicassisted extraction. AIP Conf. Proc. 2237:020069. doi: 10.1063/5.000 5289

Tan, J. B. L., and Lim, Y. Y. (2015). Critical analysis of current methods for assessing the in vitro antioxidant and antibacterial activity of plant extracts. Food Chem. 172, 814-822. doi: 10.1016/j.foodchem.2014. 09.141

Tanaka, Y., Brugliera, F., and Chandler, S. (2009). Recent progress of flower colour modification by biotechnology. Int. J. Mol. Sci. 10, 5350-5369.

Terahara, N., Saito, N., Honda, T., Toki, K., and Osajima, Y. (1990). Acylated anthocyanins of Clitoria ternatea flowers and their acyl moieties. Phytochemistry 29, 949-953. doi: 10.1016/0031-9422(90)80 053-J

Thanh, V. T., Tran, N. Y. T., Linh, N. T. V., Vy, T. A., and Truc, T. T. (2020). Application of anthocyanin natural colors from butterfly pea (Clitoria ternatea L.) extracts to cupcake. IOP Conf. Ser. 736:062014. doi: 10.1088/1757-899x/736/ $6 / 062014$

Thuy, N. M., Minh, V. Q., Ben, T. C., Thi Nguyen, M. T., Ha, H. T. N., and Tai, N. V. (2021). Identification of anthocyanin compounds in butterfly pea flowers (Clitoria ternatea L.) by ultra performance liquid chromatography/ultraviolet coupled to mass spectrometry. Molecules 26:4539. doi: 10.3390/molecules26154539

Togami, J., Tamura, M., Ishiguro, K., Hirose, C., Okuhara, H., Ueyama, Y., et al. (2006). Molecular characterization of the flavonoid biosynthesis of Verbena hybrida and the functional analysis of verbena and Clitoria ternatea F3' $5^{\prime} \mathrm{H}$ genes in transgenic verbena. Plant Biotechnol. 23, 5-11. doi: 10.5511/ plantbiotechnology.23.5

Vidana Gamage, G. C., Lim, Y. Y., and Choo, W. S. (2021a). Black goji berry anthocyanins: extraction, stability, health benefits, and applications. ACS Food Sci. Technol. 1, 1360-1370. doi: 10.1021/acsfoodscitech.1c00203

Vidana Gamage, G. C., Lim, Y. Y., and Choo, W. S. (2021b). Sources and relative stabilities of acylated and nonacylated anthocyanins in beverage systems. J. Food Sci. Technol. doi: 10.1007/s13197-021-05054-z

Voss, D. M., Grouge, S. M., and Giusti, M. M. (2020). Comparison of Hot Water and Acetone Extraction Methods on Anthocyanin Content and Color Characteristics of Butterfly Pea Flower Extracts. Columbus, OH: CFAES.

Vuong, T. T., and Hongsprabhas, P. (2021). Influences of $\mathrm{pH}$ on binding mechanisms of anthocyanins from butterfly pea flower (Clitoria ternatea) with whey powder and whey protein isolate. Cogent Food Agric. 7:1889098. doi: 10.1080/23311932.2021.1889098

Wu, L. T., Tsai, I. L., Ho, Y. C., Hang, Y. H., Lin, C., Tsai, M. L., et al. (2021). Active and intelligent gellan gum-based packaging films for controlling anthocyanins release and monitoring food freshness. Carbohydr. Polym. 254:117410. doi: 10.1016/j.carbpol.2020.117410

Xu, Z., Zhang, T., Prinyawiwatkul, W., and Godber, J. S. (2005). Capabilities of different cooking oils in prevention of cholesterol oxidation during heating. J. Am. Oil Chem. Soc. 82, 243-248. doi: 10.1007/s11746-005-1 062-9

Yanti, Y., Setiawan, T., and Lay, B. W. (2018). Antibacterial, antibiofilm and quorum sensing inhibitory activities of Clitoria ternatea anthocyanin against Streptococcus mutans. Int. J. Infect. Dis. 73, 143-144. doi: 10.1016/j.ijid.2018.04. 3739

Yoon, B. I., Bae, W. J., Choi, Y. S., Kim, S. J., Ha, U. S., Hong, S. H., et al. (2018). Anti-inflammatory and antimicrobial effects of anthocyanin extracted from black soybean on chronic bacterial prostatitis rat model. Chin. J. Integr. Med. 24, 621-626. doi: 10.1007/s11655-013-1547-y 
Yoshida, K., Mori, M., and Kondo, T. (2009). Blue flower color development by anthocyanins: from chemical structure to cell physiology. Nat. Prod. Rep. 26, 884-915. doi: 10.1039/b800165k

Yue, E., Tuguzbaeva, G., Chen, X., Qin, Y., Li, A., Sun, X., et al. (2019). Anthocyanin is involved in the activation of pyroptosis in oral squamous cell carcinoma. Phytomedicine 56, 286-294. doi: 10.1016/j.phymed.2018.09.223

Zakaria, N. N. A., Okello, E. J., Howes, M. J., Birch-Machin, M. A., and Bowman, A. (2018). In vitro protective effects of an aqueous extract of Clitoria ternatea L. Flower against hydrogen peroxide-induced cytotoxicity and UV-induced mtDNA damage in human keratinocytes. Phytother. Res. 32, 1064-1072. doi: $10.1002 /$ ptr.6045

Zhang, X., Lu, S., and Chen, X. (2014). A visual pH sensing film using natural dyes from Bauhinia blakeana Dunn. Sens. Actuators B 198, 268-273. doi: 10.1016/j. snb.2014.02.094

Zhang, Z., Cho, S. E., Dadmohammadi, Y., Li, Y., and Abbaspourrad, A. (2021). Improvement of the storage stability of C-phycocyanin in beverages by highpressure processing. Food Hydrocoll. 110:106055. doi: 10.1016/j.foodhyd.2020. 106055

Zhang, Z., Li, Y., and Abbaspourrad, A. (2020). Improvement of the colloidal stability of phycocyanin in acidified conditions using whey protein-phycocyanin interactions. Food Hydrocoll. 105:105747. doi: 10.1016/j. foodhyd.2020.105747

Conflict of Interest: The authors declare that the research was conducted in the absence of any commercial or financial relationships that could be construed as a potential conflict of interest.

Publisher's Note: All claims expressed in this article are solely those of the authors and do not necessarily represent those of their affiliated organizations, or those of the publisher, the editors and the reviewers. Any product that may be evaluated in this article, or claim that may be made by its manufacturer, is not guaranteed or endorsed by the publisher.

Copyright (C) 2021 Vidana Gamage, Lim and Choo. This is an open-access article distributed under the terms of the Creative Commons Attribution License (CC BY). The use, distribution or reproduction in other forums is permitted, provided the original author(s) and the copyright owner(s) are credited and that the original publication in this journal is cited, in accordance with accepted academic practice. No use, distribution or reproduction is permitted which does not comply with these terms. 